\title{
«Ala y Raíz». Identidad y nacionalismo en Cuba durante la República a través de Revista de Avance (1927-1930)
}

\author{
Manuel Ramírez Chicharro \\ Instituto de Historia, Centro de Ciencias Humanas y Sociales, Consejo Superior de Investigaciones Científicas, c/ Albasanz 26-28, 28037 Madrid, Spain \\ e-mail: manuel.ramirez@cchs.csic.es
}

\begin{abstract}
Submitted: 24 July 2014; Accepted: 16 September 2014
RESUMEN: El estudio aborda los modos a través de los cuales parte de la elite cultural esbozó y definió la identidad en Cuba durante el primer tercio del siglo xx. Para ello se ha analizado una de las publicaciones más relevantes del momento en Cuba, cuyo impacto también se extendió a otros países de Hispanoamérica: Revista de Avance (1927-1930). En primer lugar se expone la historiografía sobre la identidad cubana. A continuación, se esboza el contexto histórico en el cual se conformó el equipo editorial. Por último, teniendo siempre en cuenta los orígenes sociales y las afinidades ideológicas tanto de la dirección como de los demás autores, se establecen las líneas maestras de lo que para estos intelectuales caracterizaba y constituía «el ser cubano».
\end{abstract}

PALABRAS CLAVE: Identidad cubana; nacionalismo; hispanoamericanismo; antiimperialismo; negritud; criollismo

Citation / Cómo citar este artículo: Ramírez Chicharro, Manuel (2014). «“Ala y Raíz”. Identity and nationalism in Cuba during the Republic period through Revista de Avance (1927-1930).» Culture \& History Digital Journal, 3(2): e024. doi: http://dx.doi.org/10.3989/chdj.2014.024

\begin{abstract}
Ala y Raiz". Identity and nationalism in Cuba during the Republic period through Revista de Avance (1927-1930).- The following study deals with how the cultural elites defined the paradigm of identity in Cuba during the first third of the twentieth century by one of the most important publications by the time in Cuba, but also in Latin America: Revista de Avance (1927-1930). Firstly, it is exposed the historiography about the identity in Cuba. Then, It is explained the historical context in which it was Cuba, when the editorial team was formed. Finally, taking into account the social origins and ideological affinities of the editorial team and the other essayist, it is tried to be drawn what characterizes and constitutes, according to them, the "cuban nature".
\end{abstract}

KEYWORDS: Cuban identity; Nationalism; Spanish-Americanism; Anti-imperialism; Negritude; Criollism

Copyright: (C) 2014 CSIC This is an open-access article distributed under the terms of the Creative Commons AttributionNon Commercial (by-nc) Spain 3.0 License.

\section{INTRODUCCIÓN A REVISTA DE AVANCE}

La República de Cuba fue instaurada en 1902, tras cuatro años de ocupación estadounidense una vez finalizada la guerra de independencia contra España en 1898. La Constitución, aprobada en 1901, regiría el funcionamiento institucional de la nación bajo los condicionantes establecidos en los correspondientes documentos: la Enmienda Platt y el Tratado de Reciprocidad Comercial. Sin estos dos factores no puede entenderse bien el despliegue tanto de la política cubana como de su vertebración identitaria.

La Enmienda Platt restringía la libertad de actuación exterior de la República de Cuba porque debía desarrollarse en sintonía con los intereses geoestratégicos de EE.UU. En su articulado, se limitaba la autonomía económica y política del ejecutivo cubano, que no podría establecer por su cuenta ningún tipo de acuerdo con otras 
naciones sin previa aprobación del gobierno estadoundiense. Además, EE.UU. se reservaba la libertad de intervenir militarmente en Cuba cuando considerara que la inestabilidad política o social ponía en peligro los intereses norteamericanos. ${ }^{1}$

El segundo texto decisivo, rubricado por Tomás Estrada de Palma, se titulaba Tratado de Reciprocidad Comercial. Por este convenio, se estipuló que tanto EE.UU. como Cuba rebajarían los aranceles de sus mutuas transacciones comerciales un $20 \%$, pero durante el primer tercio del siglo xx el gobierno de La Habana llegó a situar esa rebaja en un $40 \%$. Esto significaba que Cuba se abastecería mayoritariamente del mercado externo, concretamente del estadounidense. Por otro lado, EE.UU. imponía a Cuba una tasa de producción de dulce, lo que desvió el flujo de inversiones nacionales y extranjeras hacia la industria azucarera.

Durante la I Guerra Mundial, el contexto internacional favoreció el crecimiento económico de la isla debido al descenso de producción de azúcar a escala mundial. ${ }^{2}$ Cuba se convirtió en el mayor exportador de este producto. Incluso una vez firmada la paz, la cotización siguió subiendo, especialmente a partir de 1919 cuando Estados Unidos liberalizó los controles aduaneros sobre este producto. A lo largo de 1920, la especulación se incrementó exponencialmente y los precios del dulce escalaron de forma imparable desde los 10 centavos en marzo, a los 22,5 centavos en junio. Los márgenes de beneficio atrajeron las inversiones. Esta inyección monetaria «liberó fuerzas productivas que parecían indicar el camino del progreso». Sin embargo, unos meses después, la recuperación de la industria azucarera en Europa, junto a otros factores, provocó una caída de los precios, la entrada en un ciclo deflacionista y la subsiguiente bancarrota (Santamaría, 2001).

A la crisis económica, le acompañó una inversión en los referentes nacionales. Entre 1912 y 1921, según apunta la profesora Bouffartigue, la élite militar perdió el prestigio obtenido en las guerras independentistas. Parte de la sociedad comenzó a pronunciarse contra la mala gestión estatal y la actuación fraudulenta de los gobiernos conservadores y liberales. La malversación de fondos públicos durante el gobierno de Menocal, el clientelismo de Alfredo Zayas y la corrupción del gobierno de Gerardo Machado durante los años veinte ahondaron en este proceso (Benjamin, 1975: 66-91; Bouffartigue, 2006: 23). Como señala Jorge Núñez, «la ruta oligárquica no condujo a la modernidad, sino a la construcción de un complejo simulacro moderno. Un espacio hedonista marcado por un tiempo circular, nuevas tensiones y la acumulación de una peligrosa melancolía revolucionaria» (Núñez Vega, 2011).

El malestar se extendió a diferentes sectores sociales, sindicados y no sindicados, generalmente de carácter urbano: estudiantado, trabajadores, agrupaciones femeninas, élites intelectuales. Ante la carencia de referentes nacionales surgió la necesidad de confeccionar un nuevo discurso nacionalista para redefinir la identidad cubana. En este punto surge esa hornada de intelectuales desde posiciones críticas y radicales, entre quienes se encontraban los futuros impulsores de Revista de Avance.

Revista de Avance nació en La Habana el 15 de marzo de 1927 de la mano de Alejo Carpentier, Martí Casanovas, Juan Marinello, Francisco Ichaso y Jorge Mañach, a quienes posteriormente se unieron José Zacarías Tallet y Félix Lizaso. Avance pretendía promocionar a los jóvenes talentos americanos de las vanguardias artísticas. En sus páginas, se publicaron desde pinturas y poemas a ensayos sobre el cine, el cubismo, el criollismo, el boxeo o el choteo, pero siempre con un pretendido enfoque transgresor e innovador.

Los directores de esta publicación provenían de una clase media, que tuvo la oportunidad de acceder a la universidad e incluso de formarse en el extranjero, algunos en España, otros en EE.UU. Su caracterización sociológica de pequeña burguesía les confirió una posición intermedia entre las clases dominantes y las clases subalternas que les permitió afrontar tareas de engarce social y de impulso nacional unitario (Bourdieu, 1999: 32). Recogieron los nuevos movimientos artísticos provenientes de Europa y Norteamérica, pero también desde una actitud más inclusiva atendieron los problemas socio-políticos que afectaban a la ciudadanía con especial atención a la población afrocubana (Said, 2006: 145).

Los editores de Avance tuvieron la capacidad de decidir cuándo mostrarse crítico y cuando condescendiente con las élites gobernantes o con la ciudadanía. Breully llegó a plantear que «[...] el nacionalismo [no] es la política de una clase social concreta. Pero tampoco podemos considerarlo como la política propia de los intelectuales» (Breully, 1990: 351). Y sin embargo, su protagonismo dentro de los movimientos regeneracionistas resulta inestimable. La combinación entre la «capitalización de la cultura» que le proporcionaba sus orígenes de clase junto a su formación, así como la afinidad con las reclamaciones de colectivos estudiantiles y laborales les confería mayor libertad de movimientos y menores ataduras socio-políticas.

$\mathrm{Su}$ actividad política puede rastrearse en las revueltas sociales de 1923. Todos ellos tomaron parte en alguno de estos eventos: Protesta de los Trece, Junta de Renovación Nacional, Falange de Acción Cubana, Asociación de Veteranos y Patriotas y el importante Grupo Minorista, ${ }^{3}$ entre otros. La mayoría integró la Liga Antiimperialista desde 1926, Juan Marinello tuvo cierta relación con el Partido Comunista desde su fundación en 1925 y algunos apoyaron públicamente los movimientos sufragistas por la obtención del voto en Cuba. Su común aversión al llamado imperialismo yankee no les impidió mantener contactos con el mundo universitario y cultural estadounidense, como se verá más adelante. En síntesis, podría decirse que las coordenadas ideológicas hacen de Revista de Avance una publicación trasgresora en lo artístico, crítica en lo político-económico y comprometida en lo social.

El título de la publicación refleja una concepción de progresión continua en todos los terrenos. Avance es sinónimo de estar a la vanguardia, pero también de afrontar el orden tradicional normalmente establecido por una minoría conservadora e inmovilista que podría llegar a conver- 
tirse en opresora. Este enfoque radical, compartido por todos los miembros de la dirección de la revista, impregnó su cosmovisión del mundo y fue utilizado por analogía en otros campos. Defendía al mismo tiempo trasgredir las antiguas concepciones y postulados artísticos para experimentar nuevas formas de expresión, como superar las jerarquías y divisiones socio-políticas que la República de Cuba había heredado del antiguo sistema colonial.

Lo artículos y ensayos de Avance pretendían analizar críticamente el momento histórico para luego actuar frente a las relaciones de poder que subordinaban a la sociedad cubana, entendidas en términos antagónicos. En lo político: metrópoli-colonia, patrono-proletario, gobierno-estudiantes, hombre-mujer. En lo artístico: figurativismo-abstracción, artistas europeos-artistas cubanos, cultura anglosajona-cultura hispana, cultura criolla-cultura afrocubana. Con ese reto como ética de trabajo, dieron preferencia entre sus páginas a artistas tan jóvenes como innovadores para enriquecer el panorama cultural latinoamericano.

Analizados los artículos publicados en Revista de Avance, se puede diferenciar dos bloques de ideas que sirven para engrosar el conocimiento sobre la identidad nacional cubana durante el primer tercio del siglo xx. Por un lado, aquellas que enarbolan las características «endógenas»: pensamiento martiano, criollismo, indigenismo y afrocubanía. Por otro, factores que aun siendo exógenos habían configurado la propia identidad mediante procesos de imitación, reacción u oposición. Es decir, lo que se ha denominado como hispanismo, europeísmo o antieuropeísmo, antillanismo, hispanoamericanismo y antinorteamericanismo. ${ }^{4}$

\section{FORJADORES DE IDENTIDAD: LA CULTURA COMO SOPORTE DEL NACIONALISMO}

\section{Patriotismo, cultura y raza}

Revista de Avance denunció que algunos cubanos practicasen el patriotierismo sin fundamentos hacia lo extranjero para ensalzar lo propio de la misma forma. Sin embargo, la voluntad de censurar lo ajeno se diluía cuando se trataba de criticar lo propio de forma constructiva, de contribuir a la regeneración nacional (Los cinco, 1929g: 243). Ante la agresión externa por parte de los Estados Unidos, una nación suele dar la espalda a lo extranjero y abrazarse a sí misma, ensalzar sus propios valores. Como asegura Tomás Castañeda, ciertos sectores de la sociedad se afanaban en hallar particularismos culturales únicamente impulsados por sentimientos patrióticos porque:

la crítica literaria cubana ha padecido siempre de necrofilia y narcisismo. [...] El optimismo provinciano de estimar que lo de casa es lo mejor (solo por ser de casa) nos llevará rápidamente al estancamiento y a la decadencia (Los cinco, 1928c) A nadie se le ocurre reclamar con la misma fuerza el bautismo de la cultura propia en todos los campos. Nadie exige el reconocimiento internacional de las matemáticas cubanas o de la biología sueca (Mañach, 1929: 130).
De esa forma, los directores de Avance pretendían justificar que ellos juzgarían con igual criterio la literatura cubana y la del resto de América.

Quienes analizaban la cultura propia frente a la extranjera con el prisma de lo patriótico, terminaron apelando a la raza como depositaria y trasmisora de dicho legado para justificar sus argumentos. En contraposición, intelectuales como Fernando Ortiz advirtieron de que raza y cultura no son términos equiparables pues:

La raza es concepto estático, la cultura lo es dinámico.

La raza es un hecho. La cultura es, además, una fuerza.

[...] hacia la forja de hechos nuevos. Lo demás sería algo así como pasarnos la vida demostrando la autenticidad de nuestros apellidos (Jarnes, 1929: 8).

Para Avance, el nacionalismo cubano tenía que ser inclusivo, no exclusivo; es decir, fundamentarse en la cultura, no en la raza. Esa cultura habría de ser sincrética, aglutinar las costumbres y tradiciones de los diferentes colectivos que integraban la sociedad cubana para que las minorías se sintieran identificadas con un mismo proyecto nacional. A la altura de 1920, intelectuales como Fernando Ortiz elaboraron un discurso nacionalista enalteciendo la diversidad étnica (Naranjo Orovio, 2003: 536). ${ }^{5}$ José Martí, fuente de inspiración para la revista, fue claro al respecto del caso mexicano: «o México sale con el indio, o no sale» (Los cinco, 1929d: 86). Para el caso que nos ocupa, o Cuba asimilaba los particularismos de negros, mestizos, hispanos y criollos, o jamás superaría sus conflictos de etnia y clase. Siguiendo al mártir de la independencia, Revista de Avance proponía construir la «nación del cubano» frente a la «patria criolla» (Rojas, 2000: 133; Bouffartigue, 2006: 20).

Otro elemento destacado de la identidad cubana fue la sociedad rural. Ramiro Guerra y Luis Felipe Rodríguez identificaron la patria con el ruralismo: la tierra y el pequeño campesino blanco, en contraposición a la población industrializada de los EE.UU., que expropiaron a los isleños parte de sus propiedades agrícolas. De forma ideal, el campo representaba el lugar donde se desarrollaba la vida sin conflictos humanos, sin diferencias de clase o raza, sin corrupción política. Y su habitante estereotipado, el campesino blanco, aglutinaba en su figura lo más autóctono al tiempo que simbolizaba la lucha contra España durante la independencia, al contrario que el negro, el haitiano, el chino, el canario o el jamaiquino (Naranjo Orovio, 2003: 524).

Junto al criollismo y al enaltecimiento de la vida rural, hay que hacer mención también a una cierta revalorización del indigenismo. En lo relativo a las raíces de lo $\mathrm{cu}$ bano, Avance aludió en ocasiones al extinto pueblo taíno. Es cierto que fue un fenómeno cultural con cierta difusión entre 1910 y 1915 , pero no tanto en los años 20’. Marinello advirtió de que el indigenismo tenía muy poca fuerza en Cuba. La búsqueda de lo autóctono y su expresión, tan patente en el arte hispanoamericano, no había tenido tanto arraigo en la isla porque apenas había sobrevivido pobla- 
ción autóctona ni quedaban vestigios orales, documentales o monumentales de su presencia (Los cinco,1930: 53).

La lengua no fue factor de identidad especialmente discutido en la revista, quizás porque no era particular de la nación cubana. La injerencia estadounidense conllevó la penetración del idioma inglés en escuelas, empresas, instituciones oficiales y medios de comunicación, sobre todo en las ciudades capital de provincia (D’Ors, 1927: 40). En la Revista de Avance, se constata cómo las élites intelectuales aceptaron la asimilación de anglicismos, pero creyeron conveniente rebajar el idioma inglés a categoría de herramienta de comunicación contractual para centros de negocio y, a lo sumo, el cine. Por otra parte, hay que recordar que a la altura de 1915 se eliminó el inglés como asignatura en la enseñanza obligatoria de las escuelas cubanas (De la Fuente, 2000: 253). En todo caso, aunque la lengua no fue un factor clave en la definición de la identidad cubana, conviene tenerla en cuenta cuando se aborde la cuestión del antinorteamericanismo.

\section{La construcción del pasado: hitos y mitos de la nación cubana}

La historia siempre responde a unas tendencias y planteamientos políticos. Nunca es totalmente neutral, ni objetiva. Se construye a partir de recuerdos oficiales que se asientan por repetición en el imaginario colectivo. Recuerdos oficiales y recuerdos admitidos, pero también pretendidos olvidos y lagunas. La historia nacional cumple su función tan solo si ayuda a justificar la razón de ser del Estado-nación, (Álvarez, Beramendi y Requejo, 2005: 30-33) y a veces incluso de la élite política. En este punto, el papel que desempeñan los historiadores parece trascendental. La unidad de la comunidad imaginada depende en parte de cuál es el conjunto de hechos, procesos y personajes señalados como esenciales, referenciales y ejemplarizantes para comprender y aceptar la necesaria unificación e independencia de la madre patria (Pérez Garzón, 2002: 11-24).

Los cinco, ${ }^{6}$ sin ser historiadores, contribuyeron a esta tarea. Por citar un ejemplo, Ramiro Guerra y Luis Araquistain pronunciaron sendas conferencias sobre la colonización española e inglesa a lo largo de la Edad Moderna. Según ellos, la comparación entre el colonialismo sajón y el hispano demostraba que España, al menos, había ofrecido la posibilidad a sus indios de terminar siendo propietarios de la tierra que trabajaban. La conferencia concluyó con una serie de datos sobre los títulos de propiedad de las empresas extranjeras asentadas en la isla entre 1898 a 1928. En este caso, también se estaba utilizando la historia para transmitir un claro mensaje aleccionador: los herederos de Inglaterra, los EE.UU., están haciendo con nosotros lo mismo que los españoles con los indios del pasado: expropiarnos el suelo y adueñarse de nuestras riquezas (Los cinco, 1927g: 87).

El relato nacionalista del pasado de Cuba también necesitaba integrar a las personalidades que, dependiendo de sus cualidades, podrían tomarse como referentes morales para los ciudadanos. Un hito, un referente para la nación, según Raúl Roa, es toda aquella personalidad que «lleva en sí una partícula de eternidades» (Roa García, 1927: 254). Según Ichaso, las personas más importantes de un país son «los académicos, los catedráticos y los ministros» (1927, 11: 274). Avance ensalzó a personalidades como Julio Antonio Mella, Enrique José Varona, Manuel Sanguily y Rubén Martínez Villena como los modelos político-sociales a seguir por la juventud cubana. Sin embargo, José Martí fue la personalidad más destacada por los ensayistas de Avance como «el alma y el motor de la invención de Cuba, como unificador de los diferentes grupos socio-culturales en ciudadanos de una misma nación» (Los cinco, 1930c: 98).?

$\mathrm{Su}$ influencia trascendía el Caribe hasta arraigar en el intelectualismo del cono sur (Los cinco, 1930c: 130). La obra de Martí vino a ser el colofón a la incompleta gesta bolivariana al norte de Panamá (Los cinco, 1930c: 131). O como ha señalado el historiador Rafael Rojas, «el espíritu de la nación tenía que personificarse en sus héroes» (Rojas, 2000, 131 y 133). La afección de Los cinco por su figura les llevó a describirlo no solo como el prototipo de intelectual comprometido, como el forjador de la mitología nacional, sino como el mejor maestro para los niños cubanos, algo que coincide con posteriores representaciones (Pichardo, 1985).

Los hitos nacionales no se nutrían solamente de viejas glorias. De todos es sabido que el deporte ha sido una de las herramientas utilizadas por el Estado para fortalecer los lazos nacionales. El boxeador negro, Eligio Sardiñas, constituye un buen ejemplo. Más conocido como Kid Chocolate, cosechó 10 derrotas por 136 victorias, 51 de ellos por knock-out. La revista se congratulaba porque no habían dado al mundo ninguna figura tan «espontáneamente perfecta» en el deporte desde el ajedrecista Raúl Capablanca, tanto que las autoridades municipales de La Habana habían pensado en ponerle su nombre a una calle en la capital (Los cinco, 1929i: 289). Kid Chocolate no solo representaba un éxito deportivo para la nación cubana. Avance lo interpretó como un paso más en la liberación y el reconocimiento social de la población negra (Los cinco, 1929e: 182). ${ }^{8}$ En lo concerniente a la problemática racial, afirmaron que «casi ningún cubano de hoy ha alcanzado con el cerebro lo que «Kid Chocolate» con los puños» (Los cinco, 1929j: 289). El deporte y la música fueron dos de las más importantes vías de progreso para la población afrocubana.

\section{El africanismo o afrocubanismo: del Anaquille a la Danza Lucumí}

Los temas y motivos de personas negras son mucho más frecuentes que los relativos al indigenismo en el discurso sobre la identidad cubana a lo largo de todo el siglo xx (Los cinco, 1929a: 5; Marinello, 1930: 42). EE.UU. justificaba la injerencia aludiendo a la inferioridad racial de los cubanos, lo cual les inhabilitaba para gobernarse a sí mismos. Mientras EE.UU. veía degradación racial en el mestizaje, algunos intelectuales terminaron interpretándolo como un factor de progreso, evo- 
lución y enriquecimiento mediante el sincretismo. Como señalara José Martí, si el pueblo cubano quería ser independiente y libre necesitaba limar las diferencias político-sociales entre blancos, indios y negros. La inclusión del negro en la vida cívica del país revalorizaría a la nación por los diferentes aportes culturales que recibía de sus habitantes, provenientes de distintas tradiciones. En síntesis, el discurso nacionalista cubano a comienzos del siglo xx intentó poner la mixtura étnica como condición favorable para la unión de la sociedad cubana frente a los EE.UU. Por este motivo, se hizo necesario reformular la «relación entre raza y nación. Si cuba era condenada al atraso y a la dependencia por ser negra, entonces lo negro tenía que ser rescatado para salvar a Cuba» (De la Fuente, 2000: 247).

A través de Revista de Avance se constata el aumento del interés hacia la negritud en Cuba. Pedro Marco observó en uno de sus artículos que:

El negro -individuo- está de moda. Norteamérica y Europa piden, incesantemente, cosas de negros. Más todavía: cosas de negros interpretadas por negros. [...] El alma negra quiere manifestarse y fecundar -literalmente- la tierra de las armonías humanas (Marco, 1929: 181).

Keyserling explica que el negro ha impregnado con sus costumbres africanas de tal forma la mentalidad y la cultura del blanco que lo ha sensibilizado con su mundo. De ahí, por ejemplo, la atracción que tanto en EE.UU. como en Cuba ejercía el jazz entre la alta sociedad (Castañeda León, 1929: 110).

Entre 1920 y 1930 se incrementó el número de libros sobre la negritud en Cuba, pero también en EE.UU. El poeta Copper Sun, hombre negro norteamericano, acaparó la atención del público tanto dentro como fuera de su país (Los cinco, 1927d: 318). Luis Felipe Rodríguez, en «Danza Lucumí», uno de cuyos fragmentos se publica en Avance, ilustra la opresión que sentía el afrocubano obligado a trabajar de sol a sol en el ingenio azucarero (Rodríguez, 1930: 47). Alejo Carpentier también contribuyó con relatos y poemas a tratar esta problemática. En «Liturgia», anticipa el sentir de su primera gran novela, ÉcuYamba-Ó (1933):

[...] En sus ojos miran / Ojos de cartón:

¡brujo de Senegal,/ Tabú y carnaval! [...]

/Endoco endiminoco, / Efimere bongó. /

Enkiko bagarofia / ¡yamba ó! [...]

El yamba gritó: / iyamba ó! /

¡quien robe comida, / Palo tendrá! /

Un negro corrió /

¡yamba ó! / ¿Tú la cogiste? /

¡Por la roca rodó! (Carpentier, 1930: 260).

La guitarra y los gitanos, la guitarra y los negros. La llegada de Lorca a La Habana supuso un revuelo mediático que tuvo resonancias en toda la prensa de la isla. El poeta granadino no era el autor aún de los grandes dramas de teatro. No había publicado Yerma, Bodas de Sangre o La casa de Bernarda Alba. En Cuba era conocido por su
Romancero Gitano. Algunos poemarios (Pereda Valdés, 1927: 316), ${ }^{9}$ también ciertas pinturas, transmiten esa mezcla de victimismo y fascinación por la simbiosis entre el negro y el gitano, con la guitarra como enlace entre los dos. Luis Cardoza y Aragón explicó que esto puede deberse a que tanto el gitano como el negro compartían cierto grado de marginación en sus países, pero al mismo tiempo resultaban imprescindibles para explicar las identidades nacionales de España y Cuba (Cardoza y Aragón, 1930: 74).

Las pinturas, caricaturas y poemas de Revista de Avance recogen algunos de los arquetipos que se mantenían sobre la población negra y mestiza. Los cuadros y caricaturas expuestos en Revista de Avance aglutinan la mayor atención hacia la negritud de entre todas sus publicaciones. Jaime Valls Díaz nacido en Cataluña, pero cubano de adopción, fue quizás uno de quienes mejor supo reflejar la naturaleza de lo negro (Los cinco, 1927e: 72A72C). Como señaló Jorge Mañach al respecto, Valls supo captar en la población negra, afrocriolla, el espíritu de lo dionisíaco y lo sensual, pero también la elegancia natural de su físico escultórico (1930: 112).

Eduardo Abela es otro de los pintores de Avance en esta temática. Sugiere en sus cuadros el exotismo del tabaco, las palmeras, el primitivismo y el naturalismo del cuerpo negro en escorzo mientras baila una rumba ( $\mathrm{Za}-$ mora, 1929, 18). Son muchos los artistas que contribuyen con su paleta a resaltar, victimizando o glorificando, la figura del negro. Domingo Ravener, José Clemente Orozco, Conrado W. Massaguer, Carlos Mérida, López Méndez, Roberto Arciaga y García Maroto. ${ }^{10}$

Los hombres negros suelen estar asociados al mundo rural. El 80\% de las ocasiones está trabajando con bueyes, arando la tierra, intentando sacarlos de un charco enfangado donde quedaron atascados (Imágenes 1, 2 y 3). También lo encontramos transportando agua desde el pozo, cortando caña, contemplando la tierra que está por aventar y sembrar (Imágenes 4 y 5). Sus rostros apenas denotan sufrimiento, pero la posición de sus cuerpos transmite sensación de esfuerzo y laboriosidad. En contadas ocasiones encontramos variantes a este tema. Por ejemplo, el manisero o el burgués, cuyo traje y sombrero blanco hace resaltar aún más si cabe el tono de su piel

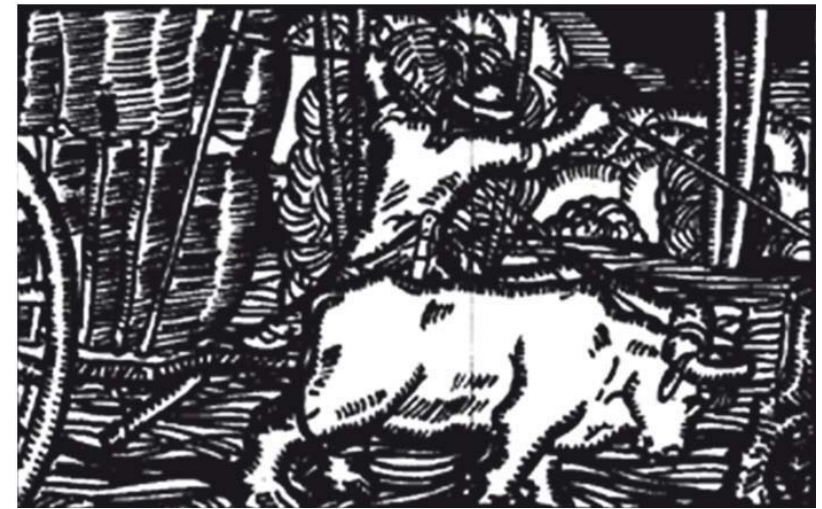

Imagen 1: Eduardo Abela, Revista de Avance, 1927, 3: 58. 


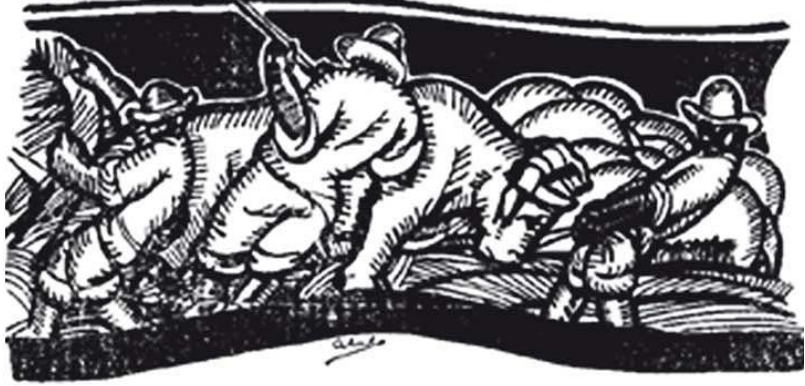

ImAGEN 2: Eduardo Abela, Revista de Avance, 1927, 5: 110-111.

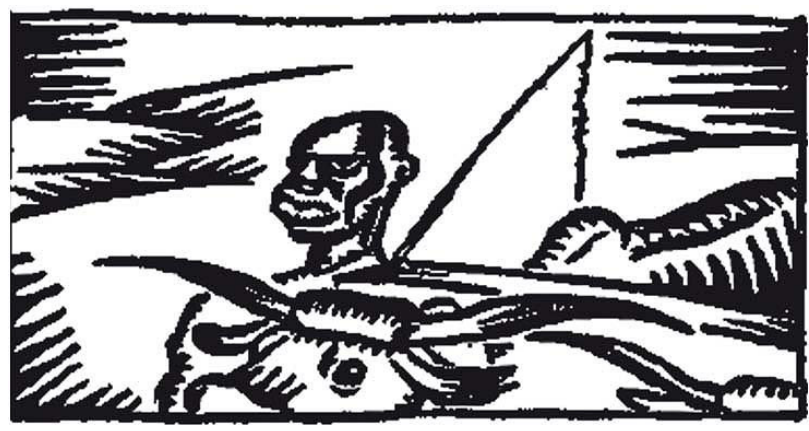

ImAgen 3: Anónimo, Revista de Avance, 1927, 4: 96.

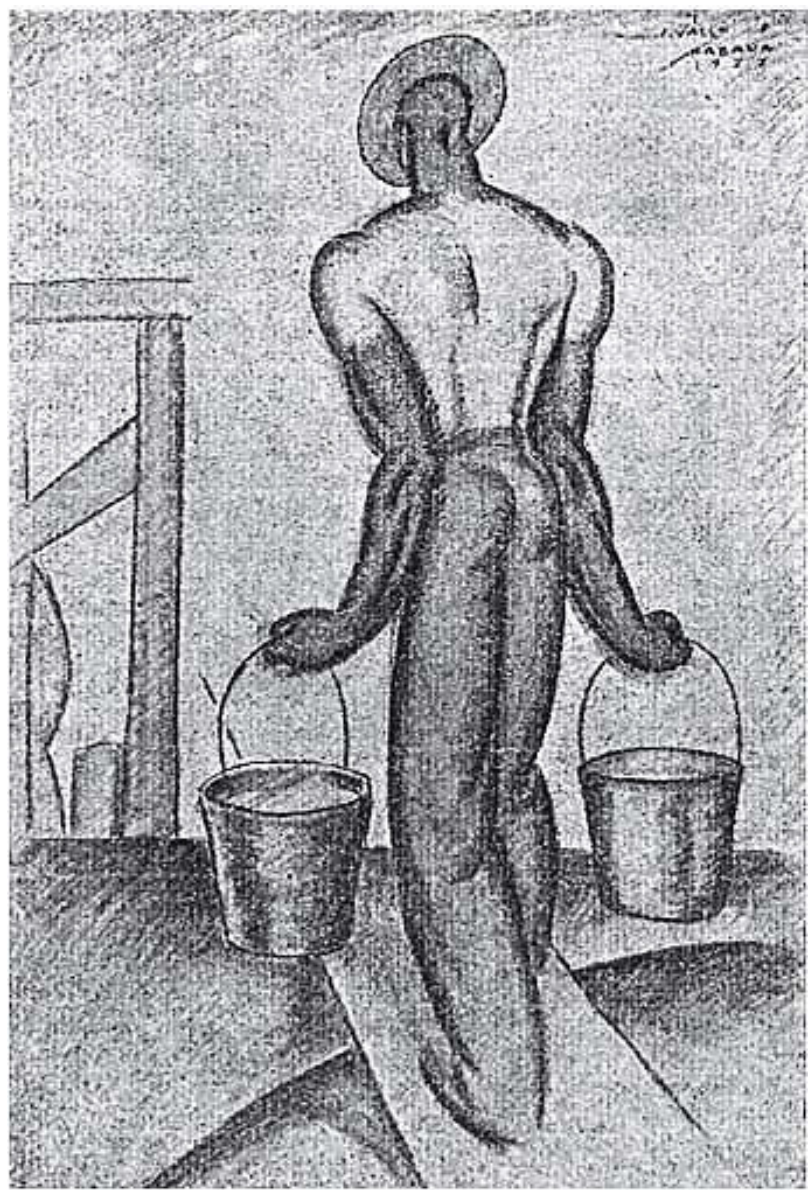

IMAgEN 4: Jaime Valls, Revista de Avance, 1929, 41: 363.

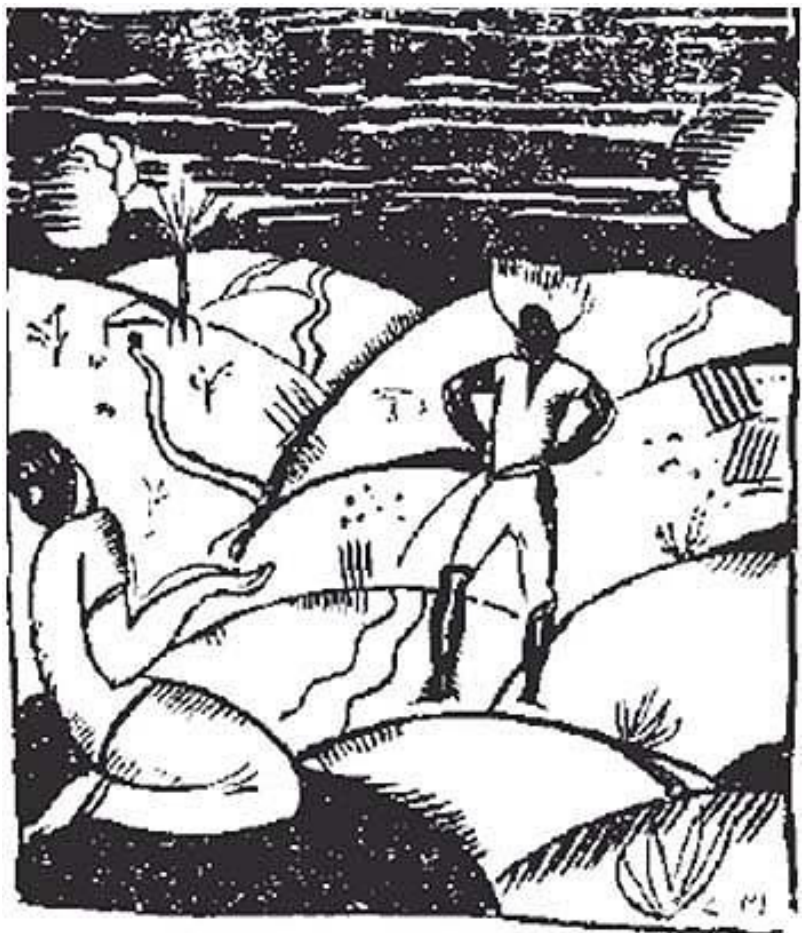

Imagen 5: Anónimo, Revista de Avance, 1927, 2: 27.

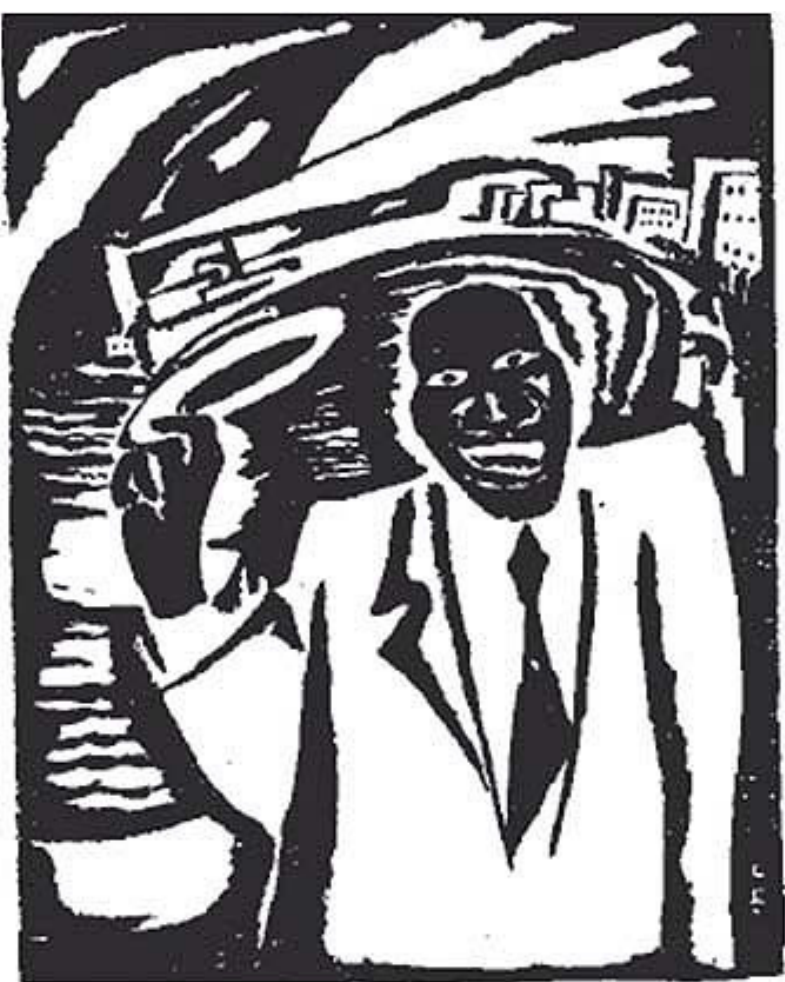

Imagen 6: Anónimo, Revista de Avance, 1927, 9: 229. 
(Imagen 6). Por lo general, reinciden en su fortaleza física, el poderío de sus músculos, sus brazos y abdominales, como si se tratase de un Adonis o Hércules negro con sombrero de paja (Imagen 7).

La mujer negra, por su parte, está más vinculada a la santería y la desnudez. Las santeras, vestidas de blanco, no suelen personificar lo dionisiaco y visceral del rito afrocubano, no bailan, no rezan, no cantan, ni fuman tabaco. Con sus atuendos característicos: pasean por la calle hablando con hombres -siempre negros- o realizando tareas cotidianas. Aparece también algún retrato o primer plano (Imágenes 8, 9 y 10). Por otro lado, resultan destacados los cuadros, caricaturas, bocetos y grabados que atañen a lo sensual de las mujeres negras y mulatas. Jaime Valls destaca su desnudez plena, en ocasiones solo el cuerpo, sin mostrar siquiera la cabeza, como una Venus de Milo o de Willendorf afrocubana cuyas curvas y volúmenes vendrían a constituirse en metáfora de su fertilidad y voluptuosidad, como si su estructura física estuviera destinada al sexo (Imagen 11). Enric Casanovas combina el mundo del trabajo y la sexualidad mostrándonos a una mujer negra, con los pechos al aire, portando un cesto de cacao sobre su hombro izquierdo y sonriendo al espectador, sin dolor en sus facciones, mirando fijamente la lente que le apunta y por tanto la pupila de quien la observa al otro lado. Es una mujer segura y atrevida que rompe el canon de mujer sumisa y recatada más propio de las mujeres blancas y burguesas de la clase media, según las costumbres de la época (Imagen 12). Nogueira, por su

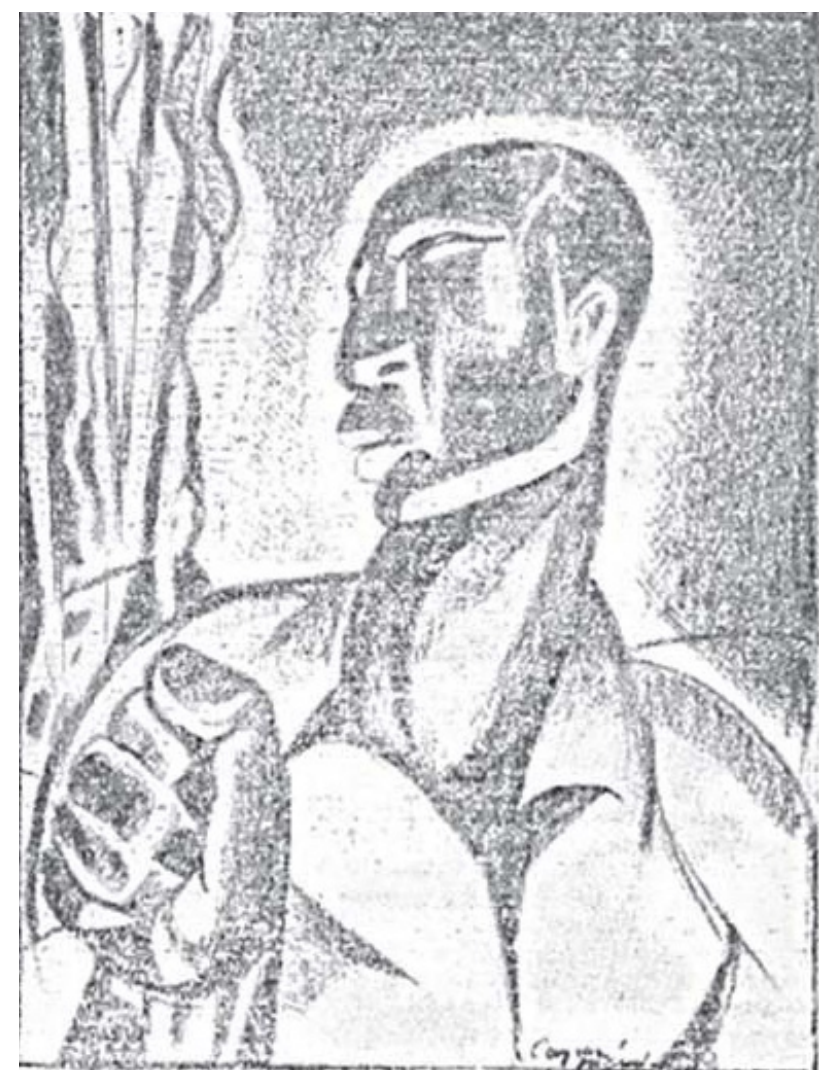

Imagen 7: López Méndez, Revista de Avance, 1929, 31: 22. parte, prefiere tomar el modelo iconográfico de las tres gracias de Rubens y trasladarlo a las mujeres negras que se bañan en la orilla del río en un descanso del trabajo, se desprenden de sus ropas, pero mantienen el pañuelo blanco anudado sobre la cabeza y sus pendientes redondos y metálicos (Imagen 13). El exotismo y la sensualidad que

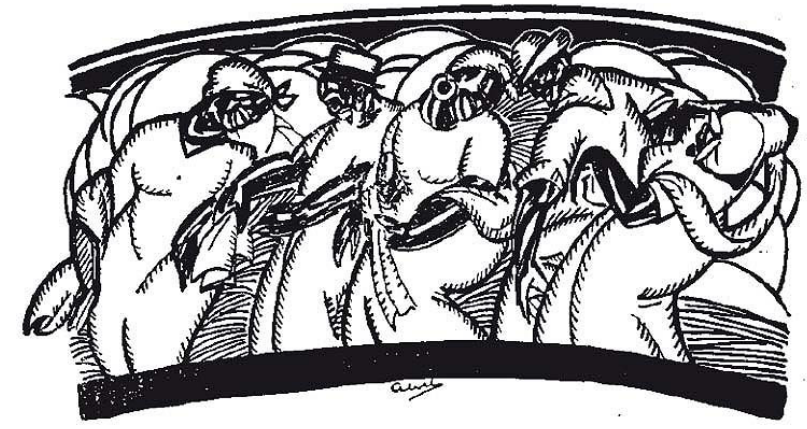

Imagen 8: Eduardo Abella, Revista de Avance, 1927, 3: 61.

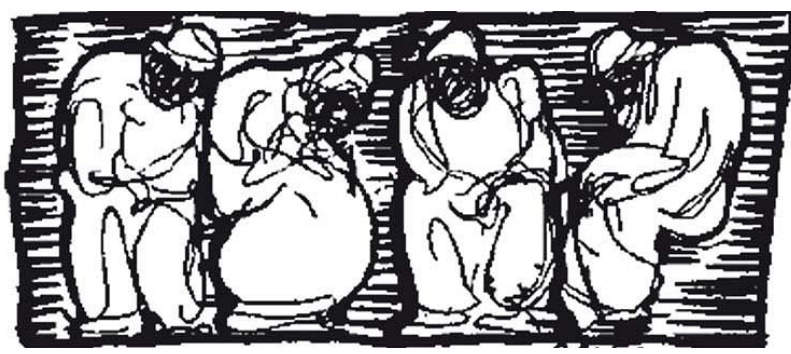

IMAGEN 9: Eduardo Abella, Revista de Avance, 1927, 6: 132.

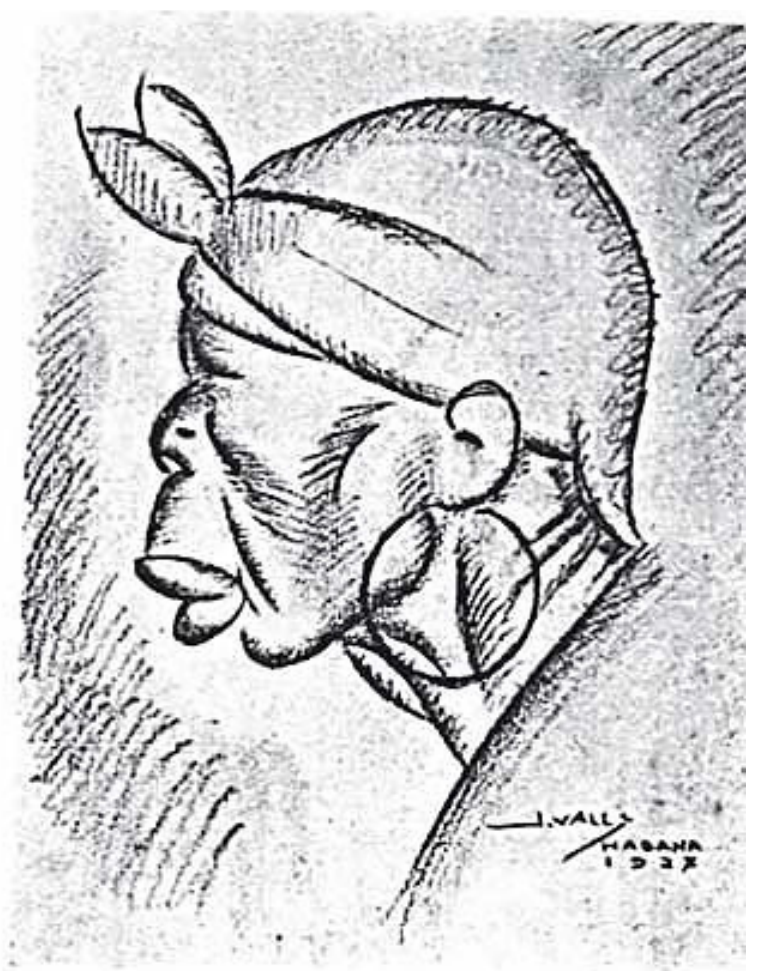

Imagen 10: Jaime Valls, Revista de Avance, 1927, 15: 72C. 


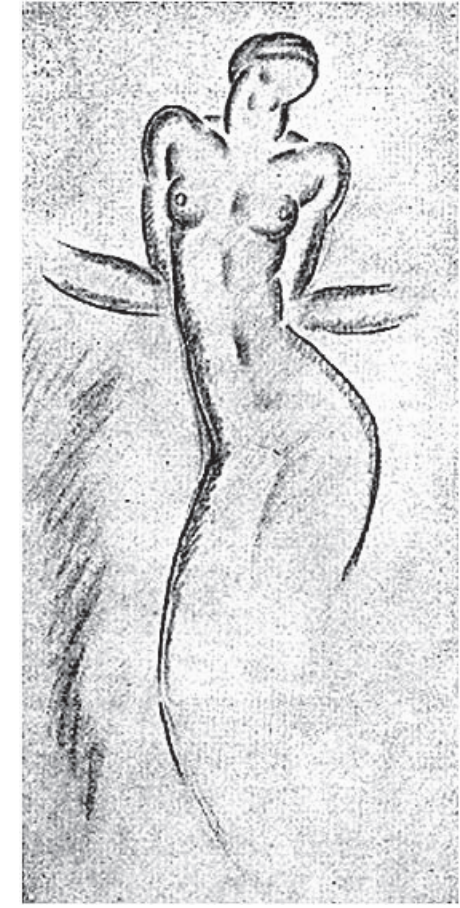

IMAgen 11: Jaime Valls, Revista de Avance, 1929, 41: 367.

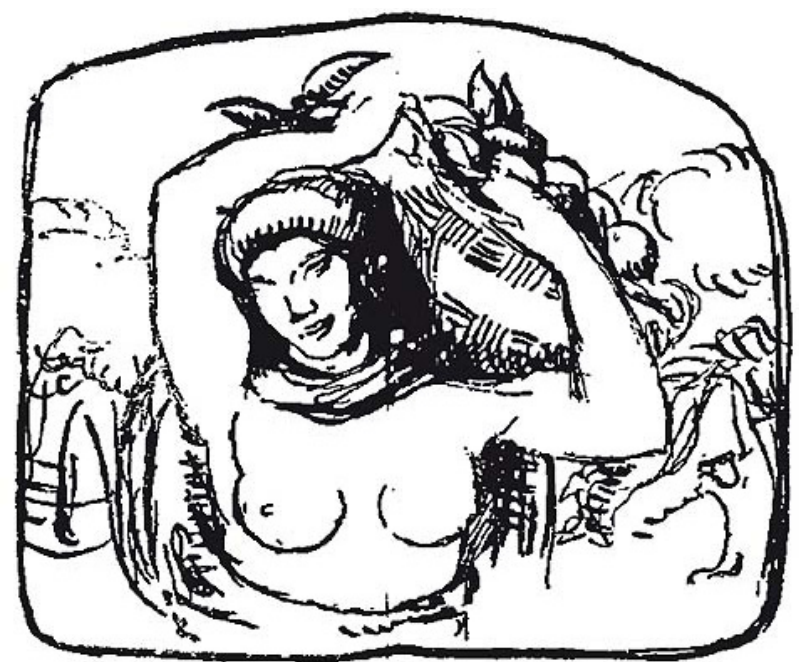

Imagen 12: Enric Casanovas, Revista de Avance, 1927, 4: 83.

se percibe en estas representaciones femeninas podría enlazar con el mito de la mulata como «seductora por naturaleza» estudiado por Juan Andreo García para el siglo XIX (2013: 181).

Ahondando en el análisis de género, podría decirse que las mujeres negras, al contrario que los hombres, aparecen representadas en varias ocasiones junto a niños negros, nunca blancos, ni mulatos. Esto permitiría definir una línea de pensamiento en lo referente a la raza y el género. Según esta iconografía, la mujer negra sería trabajadora dentro y fuera del hogar, al tiempo que cuidadora y maestra de sus hijos, como en la pintura de Alva de la Canal donde una niña permanece mirando las actividades

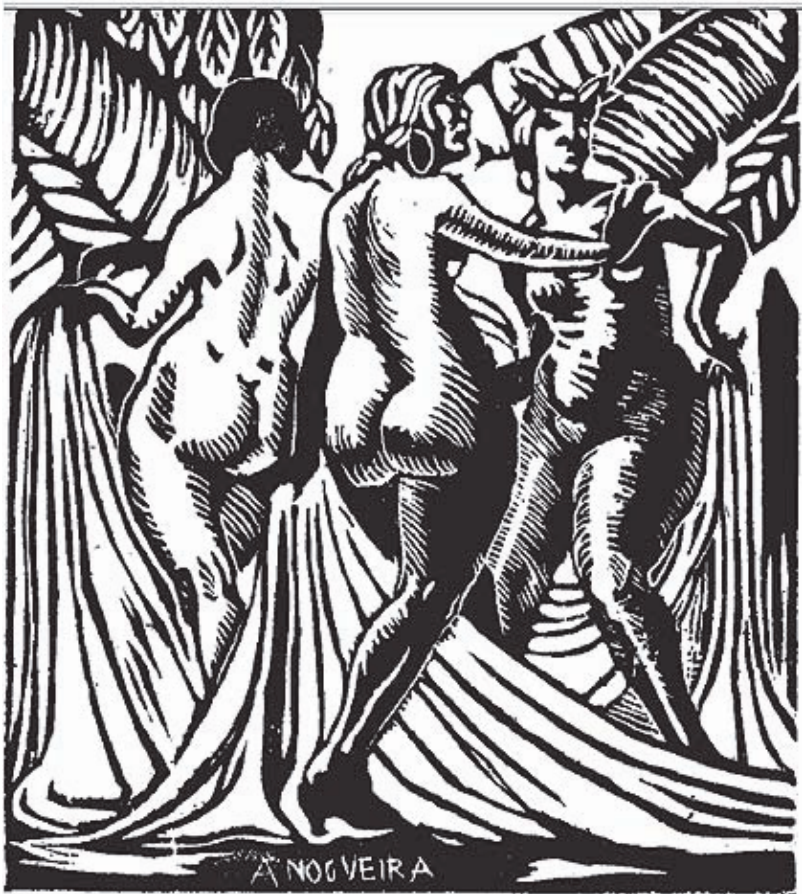

Imagen 13: Nogueira, Revista de Avance, 1929, 39: 298.

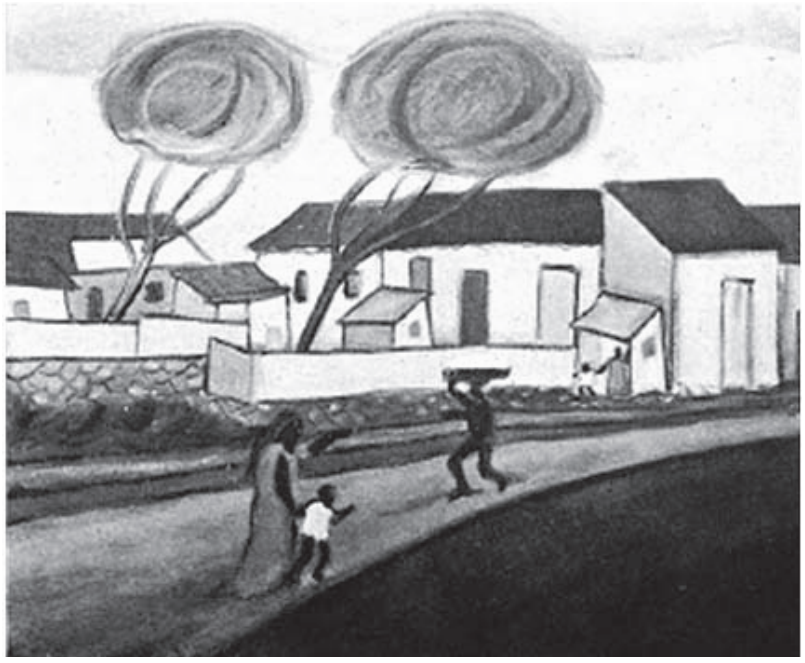

Imagen 14: L. Romero Arciaga, Revista de Avance, 1927, 5: $112 \mathrm{~B}$.

su madre que limpia a orillas del río. Es decir, aunque no encontramos a despalilladoras, ni torcedoras, aunque no aparecen creches en casas de familias adineradas, Revista de Avance no resulta innovadora respecto a los modelos patriarcales que durante aquellos años delimitaban las relaciones de género (Imágenes 14, 15 y 16).

La música se constituyó en elemento destacado de la cultura afrocubana. Los cinco afirmaron que el tronco de la música cubana se sustentaba sobre dos raíces folclóricas: la tradición criolla y la afrocubana, de donde surgieron la habanera, el songo y el danzón (Los cinco, 1929f: 217). Sin embargo, críticos como Eduardo Sánchez de Fuentes afirmaron que la música cubana estaba exenta de esencias afri- 


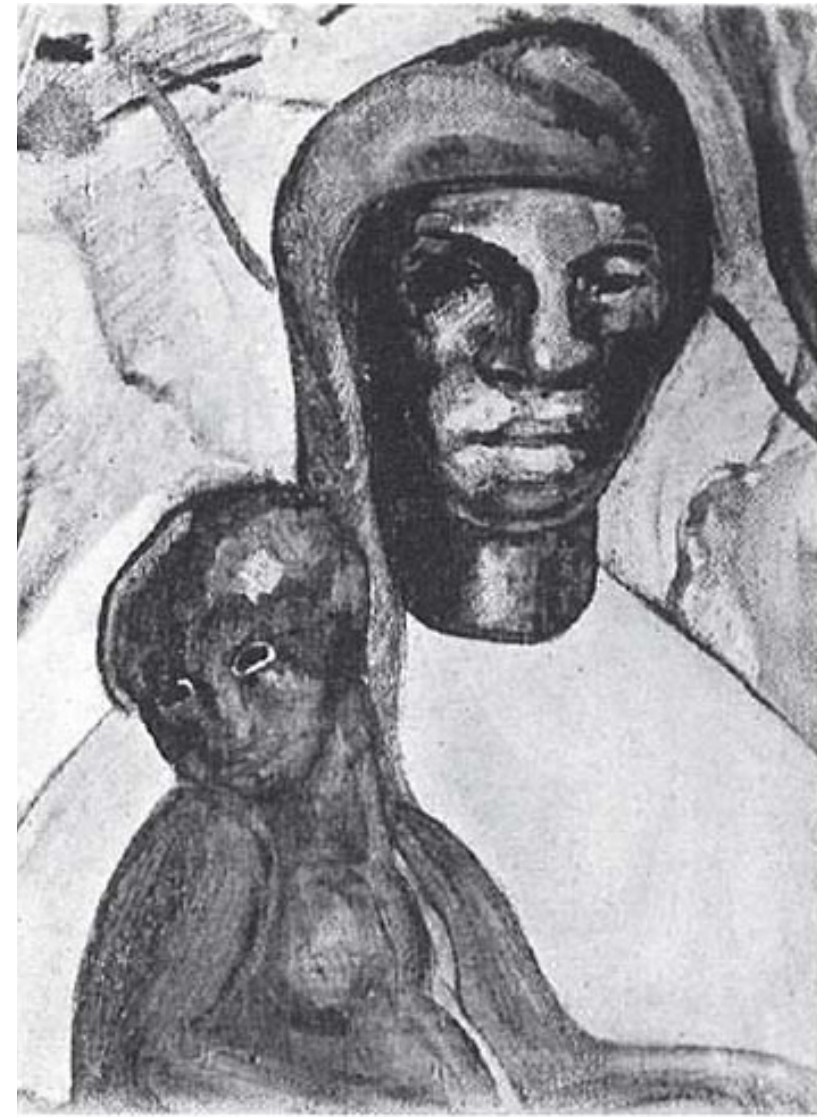

IMAGEN 15: Domingo Ravenet, Revista de Avance, 1927, 8: 204B.

canistas, mientras que otros añadieron que estos elementos eran menos relevantes que los legados por Europa. Posteriormente, Salvador García Agüero ha interpretado que la negación de la música negra o sus influencias sobre los ritmos cubanos fuera el fiel reflejo de una fobia hacia esta población que aún pervivía bajo una República supuestamente igualitaria (De la Fuente, 2000: 260-261).

Pedro Sanjuán fue una de las figuras más relevantes en la defensa y promoción del negrismo en la música cubana de los años 20' (Perón Hernández, 2012). Fundador de la Orquesta Filarmónica de La Habana, estrenó Babaluaye y Anaquille, en el cual introdujo música de Amadeo Roldán y escenificación de Alejo Carpentier. Con la dirección de este ballet, Sanjuán quería demostrar que África no sólo ha aportado a la civilización la percusión y el frenesí (Los cinco, 1929k: 314; Ichaso, 1930b: 158). Amadeo Roldán, por su parte, presentó al público La Rebambaramba (que en jerga afrocubana significa escándalo), donde quiso simular los ritmos nativos y lo folklórico que de su arte había quedado en Cuba (Ichaso, 1928: 244).

El crítico Jeanneret publicó en Avance un artículo titulado «El negro y el Jazz». Reivindicaba la reconsideración del papel del negro y sus tradiciones africanas en la música cubana. La negritud, decía, ha aportado a América el ritmo del tam-tam y los tambores por encima del violín, cuya primacía en la orquesta ya no era tan evidente como en el siglo XIX. El culmen del legado africano fue el

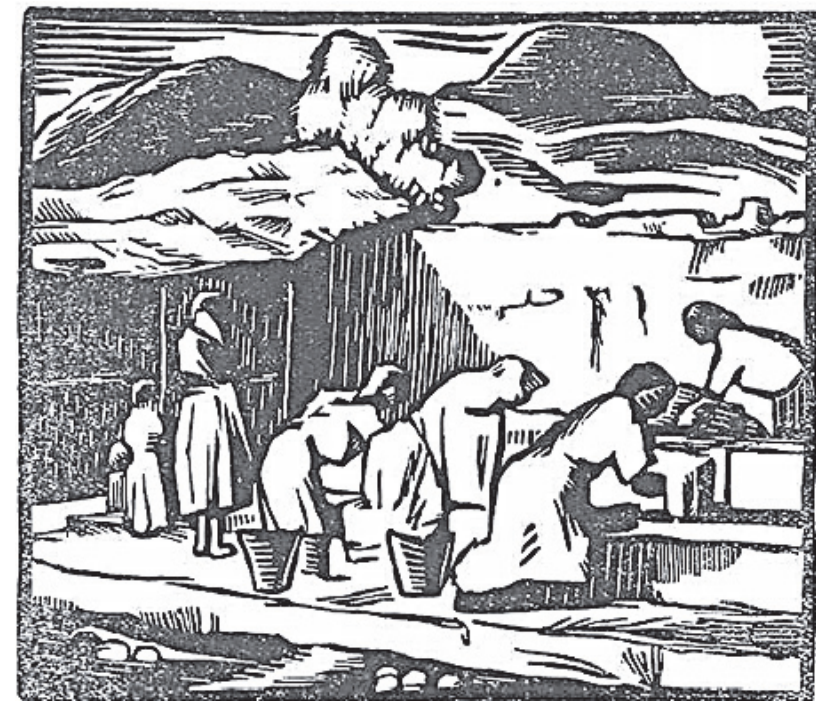

Imagen 16: Alba de la Canal, Revista de Avance, 1929, n. 32: 41.

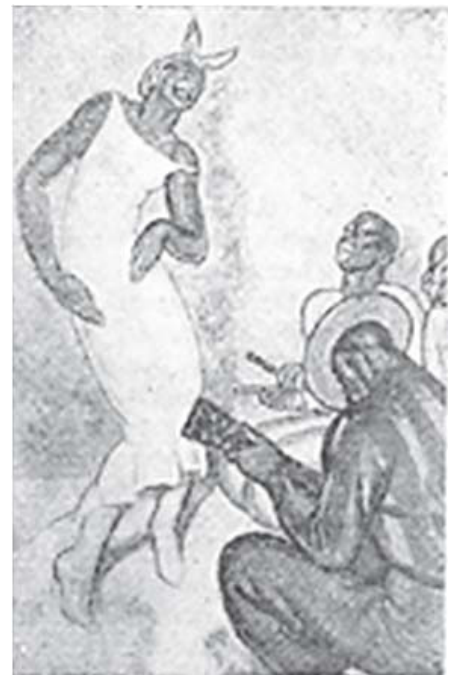

Imagen 17: Jaime Vals, Revista de Avance, 1928, 9: 241.

jazz, que como música de baile era más demandada por los blancos que por los negros, y se había constituido en un símbolo más de la identidad isleña (1927: 314).

En esta línea, los modelos iconográficos más utilizados para representar a la población afrocubana en Revista de Avance están relacionados con la música y el baile. Destaca el realizado por Jaime Valls que muestra a una mujer negra, estilizada, con un vestido largo blanco mientras baila salsa al compás que le marca su orquesta en un local nocturno (Imagen 17). Por su parte, Gropper elige modelos masculinos vinculados al mundo del espectáculo, traje y pajarita blanca, bastón en mano, brazos abiertos intentando contagiar al público (Imágenes 18, 19 y 20). En ambos casos llama la atención su sonrisa intensa.

El ennegrecimiento de Cuba fue preocupación frecuente en los tiempos de Revista de Avance. ${ }^{11}$ Las provincias orientales de la isla recibían constantemente inmigración negra semiesclavizada en los latifundios e ingenios 


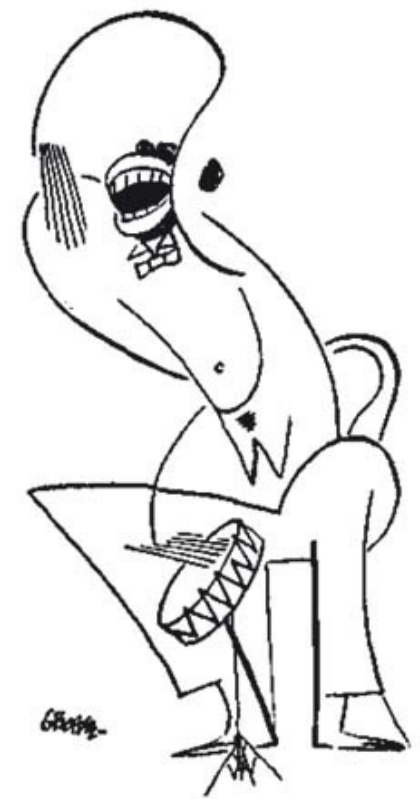

IMAGEN 18: William Gropper, Revista de Avance, 1927, 10: 267.

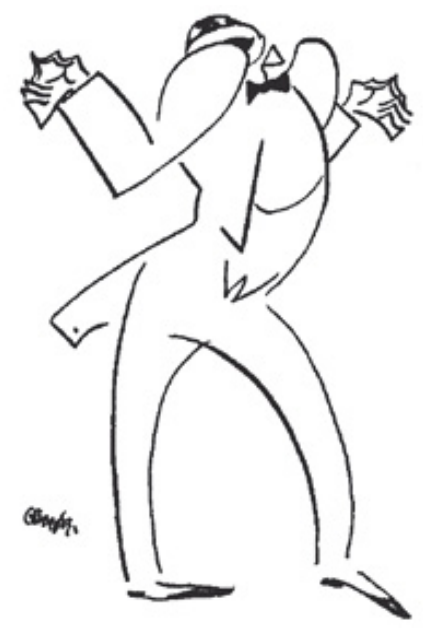

Imagen 19: William Gropper, Revista de Avance, 1927, 17: 137.

de propiedad estadounidense. Como afirma el viajero Arnoldo Roller en el artículo «El productor negro y el oro blanco de Cuba», publicado en Pluma, se pagaban 25 pesos por cada trabajador suministrado, que pasaba a ser confinado en un plantío. La esclavitud continuaba practicándose para sacar adelante la producción azucarera que demandaban los mercados (Los cinco, 1929n: 320). ${ }^{12} \mathrm{El}$ autor americano cae sin embargo en el idealismo de pensar que los negros eran tratados con los mismos privilegios que los blancos y tenían acceso a idénticos puestos de trabajo. Los cinco aplaudieron el mérito que tuvo el escritor para admitir la implicación de su país en ese negocio, pero le criticaron la visión idealizada que tenía de las condiciones de vida del negro en Cuba. Al mismo tiempo, ven la masiva inmigración de haitianos y jamaiquinos como un problema, no tanto por su color de piel

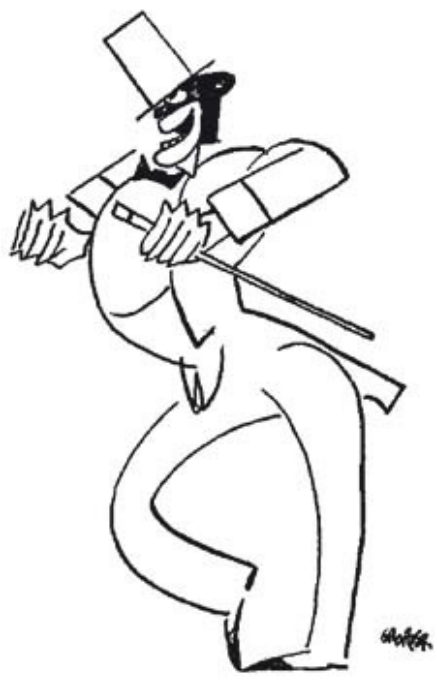

IMAgEN 20: William Gropper, Revista de Avance, 1928, 1: 14.

como por su pobreza intelectual (1929h: 287). Algunos autores, como Domingo Quiroga, reclamaron públicamente un mejor tratamiento hacia la población negra que, como la blanca, luchó y vertió su sangre en la Guerra por la Independencia de Cuba: «Eres negro, pero cuando la tralla nos cruza a los dos por igual, brota la misma sangre roja de tus heridas y de las mías» (1929: 167).

El racismo fue otra cuestión importante en el debate sobre la identidad y uno de los asuntos públicos más en boga a la altura de 1927. Los cinco, en principio, se mostraron en contra. De hecho, tuvieron presente a lo largo de la publicación las palabras de Martí: «Hombre es más que blanco, más que mulato, más que negro. Cubano es más que blanco, más que mulato, más que negro. En los campos de batalla, muriendo por Cuba, han subido juntas, por los aires, las almas de los blancos y de los negros».

$\mathrm{La}$ inferioridad racial era uno de los problemas que afectaba a las relaciones entre afrocubanos y blancos. ${ }^{13} \mathrm{~A}$ lo largo de la publicación se encuentran importantes ejemplos en los que se reivindicaban reformas en política educativa para que las nuevas generaciones crecieran sin este tipo de prejuicios. Al fin y al cabo, «La incultura no estriba en la materialidad del daño, sino en la afrenta de la postergación, en esa marca de pretensa y gratuita inferioridad que clavamos sobre la piel [...] del hombre de otra raza» (Los cinco, 1930b: 98).

Los artistas y ensayistas de Avance simpatizaban con Haití cuando se trataba de criticar la injerencia estadounidense (Morand, 1929: 20), o cuando intelectuales de otros países infravaloran su humanidad reduciendo a sus habitantes a meros motivos artísticos (Los cinco, 1929c: 64). Sin embargo, la población haitiana, mayoritariamente afrodescendiente, fue señalada como una amenaza para el blanqueamiento de los cubanos como agente del progreso. Algunos escritores de Avance se mostraron en contra de la inmigración de haitianos y jamaiquinos ante el riesgo de una nueva africanización social. En Avance, los haitianos eran considerados como seres bárbaros, sin capacidad ni 


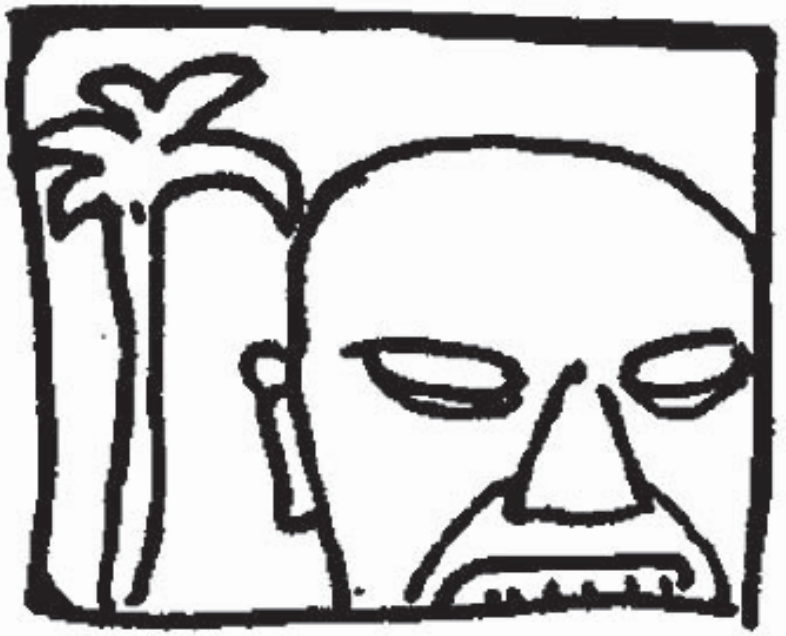

IMAGEN 21: Roberto Montenegro, Revista de Avance, 1927, 6: 134

formación para aportar algo positivo a la cubanidad (Naranjo Orovio, 2001). Si se va más allá de la descripción formal de algunas caricaturas publicadas en la revista, puede encontrarse esta problemática de forma tangencial. En contraste con el guajiro trigüeño o blanco bien ataviado, paseando por el campo o charlando con guajiras, contrasta la imagen del negro salvaje en plena naturaleza. Sus facciones recuerdan a las máscaras yorubas o vudúes que servían para espantar a los malos espíritus. Sus facciones, tersas, tensas y anguladas, sus dientes afilados, su mirada fija sin pupilas espanta al espectador y saca a relucir el lado más bárbaro de la afrocubanía (Imágenes 21 y 22).

\section{LOS ELEMENTOS EXÓGENOS DE LA IDENTIDAD CUBANA: ENTRE EL HISPANISMO Y EL ANTINORTEAMERICANISMO}

\section{Hispanismo. Asunción maternal}

A la hora de definir una identidad cultural, los cubanos buscaron sus referentes más inmediatos. La herencia del colonialismo hispano sirvió como punto de partida para adaptar, rechazar o reinventar muchas de las costumbres y tradiciones que se mantenían a la altura de 1920 . Para Luis Araquistain, solo los españoles habían sabido llevar el germen de la nacionalidad y la civilización desde Europa, al contrario que Francia o Gran Bretaña (Naranjo Orovio, 2003: 530). Por su parte, Ramiro Guerra afirmó en 1924 que la inmigración española constituyó, y seguía constituyendo en los años 20 , el «núcleo básico de la nación», en contraposición a la llegada de haitianos y jamaiquinos, que se aceleró a partir de 1917 (Naranjo Orovio, 1998: 230). Esto se debía al alto porcentaje de población española que aún residía o emigraba hacia la isla, como se puede observar en los censos de la República de Cuba realizados en 1907 y 1919.

La herencia cultural de España fue un aspecto discutido en los artículos de Avance a lo largo del año 1927. Manuel Aznar y Jorge Mañach debatieron al respecto de

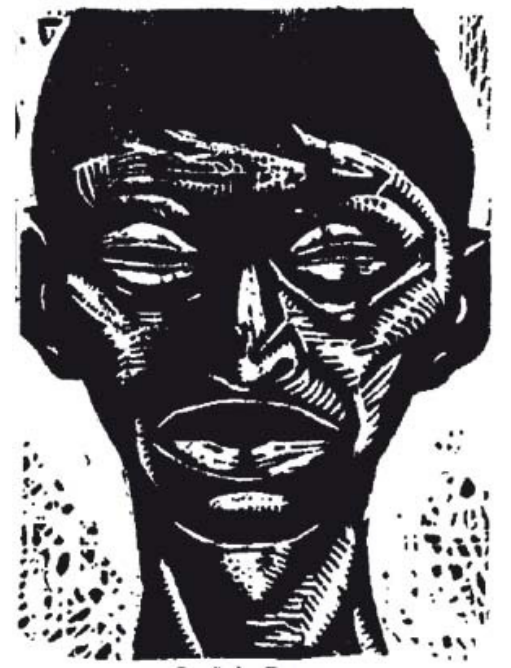

ImAGen 22: Carlos Enríquez, Revista de Avance, 1927, 8: 195.

unas declaraciones realizadas por Franz Tamayo. Posteriormente, este y Ramiro de Maeztu intercambiaron una serie de breves ensayos epistolares sobre la cuestión. El escritor boliviano entendió la pervivencia del llamado universalismo hispano de Maeztu, no tanto como el predominio o la posición referente que continuaba desempeñando la cultura de la antigua metrópoli en las nuevas naciones independientes, sino como un residuo racial sinsentido, tiranía universal, cadáver subyugante resucitado a golpe de nostalgia imperialista. Al fin y al cabo, un sistema colonial tiende a ser ecuménico y «unir a todos los hombres bajo la misma ley», imponer su visión del mundo, su idioma, sus costumbres. De ahí que Tamayo terminase tildando la interpretación de Maeztu como de «tiranía universal» (Tamayo, 1927: 95). Rufino Blanco-Fombona así lo declaraba en otro artículo: «Madrid es injusto, ha sido injusto con lo genuino de América [...] El desconocimiento -subestimación- de los valores nuestros sigue siendo norma apenas -Unamuno, Díez Cañedo...- quebrantada» (Los cinco, 1930i: 250). Cuba y España tendrían que ser entendidos como dos pueblos, dos confraternidades humanas sin jerarquías epidérmicas, dos grupos que respetaban sus diferencias humanas. Los cinco veían que el mejor medio de comunicación entre ambas comunidades sería la lengua, por donde habría de moverse la cultura de tradición hispánica para, aprovechando el común origen, intercambiar lo mucho que les quedaba por darse a conocer.

A pesar de las críticas y las denuncias con carácter retroactivo, España nunca desapareció de la definición identitaria de lo cubano. La revista no solo dedicó artículos y conferencias especiales a Goya, Góngora, Lorca, Salvador Dalí, Ramón y Cajal, Gregorio Marañón, Ramón Gómez de la Serna, Antonio Machado, Fernando de los Ríos, Miguel Unamuno, Américo Castro y Menéndez Pidal, entre otros (Los cinco, 1928b: 108). También recibió textos de Eugenio D’Ors, Ortega y Gasset, García Maroto, Pedro Salinas, Luis Cernuda, Dámaso Alonso y Juan Ramón Jiménez, así como pinturas de Juan Gris y 
Pablo Ruiz Picasso (Maroto, 1930: 152). Por otra parte, el equipo de Avance se esforzó por incrementar los lazos entre naciones latinoamericanas en la búsqueda del «universalismo de carácter americanista».

\section{Americanismo y antillanismo. La hermandad invertebrada}

Los Estados Unidos de Norteamérica se habían establecido como hermano mayor o como poder de referencia obligada. Desde la propia guerra de independencia de Cuba y con la construcción del canal de Panamá, el gobierno estadounidense había ganado presencia en la zona. Para hacer frente a esa amenaza, había brotado un sentimiento de hermandad hispanoamericana, sin que esto derivase en la creación de una federación o confederación de Estados. A lo sumo podría citarse la Liga antiimperialista, de 1926, a la que pertenecieron algunos miembros de la publicación.

Revista de Avance estuvo constantemente preocupada por «la cuestión americana» (Marinello, 1928: 7). Los cinco interpretaron el sentimiento identitario como voluntad de ser. «En la voluntad de ser argentino encuentran los habitantes de la Pampa el verdadero sentido de su argentinidad». En la voluntad de ser americano, los habitantes del continente podrían haber hallado también el deseo de cultivar su «afinidad espiritual y los enlaces ideológicos comunes». En otras palabras, "América tenía que hacerse a sí misma, sin intervención de EE.UU. o Europa, solo mediante su deseo de serlo» (Los cinco, 1929m: 319; Lizaso, 1930: 12). Para Lizaso en concreto, su historia podría resumirse «compendiando los valores genuinos forjados en la propia América», pero no se refiere a una voluntad de ser, a una comunidad imaginada. Concebía el americanismo más bien «como un ideal de valores vitales» y no como una entidad política o unos lazos de cultura transnacional (Lizaso, 1929: 358). Al fin y al cabo, «su América» aún no había tenido una oportunidad.

La hermandad americana había sido un sueño, una actitud o como mucho un propósito mal definido (Lizaso, 1930: 11). Al respecto, Pedro Enríquez Ureña demostró el fallido intento de confeccionar una historia de la literatura hispanoamericana, sustentada únicamente por un reducido número de intelectuales de renombre como Bello, Montalvo, Martí, Darío o Rodó. De hecho, a la altura de 1928 se decía que no había en Venezuela ningún escritor menor de cincuenta años con reputación, no ya a nivel mundial, sino simplemente en el mercado de lengua castellana (Los cinco, 1928f: 291).

La vanguardia, el espíritu de renovación y la fuerza del cambio constituían el hilo conductor de los debates. Los artículos dedicados al hispanoamericanismo no fueron una excepción. El discurso más repetido en la revista versaba sobre cómo reforzar los lazos que unían a la comunidad hispanoamericana. Sin embargo, había un problema que asolaba a todo el continente durante el primer tercio del siglo: las jóvenes repúblicas estaban siendo dirigidas por viejos mandatarios. Había cambiado el nombre, no la antigua definición de lo nacional.
Sin duda, los adolescentes eran el colectivo principal hacia el que iba dirigido el mensaje más insistente de la revista. Cada vez había más estudiantes de secundaria y de universidad, bien formados, con deseo de reformar el mundo en el que habían crecido, para protagonizar el cambio que necesitaba la sociedad cubana. La juventud, defendía Avance, se podía constituir en los años 30' como un bloque de oposición y acción contra las «dictaduras opresoras y anticuadas», que en lugar de ayudar en la liberación nacional y la confraternidad hispanoamericana favorecían los intereses estadounidenses. El fermento se encontraba en ellos, solo había que despertar el interés y la camaradería en pos de un objetivo común. ${ }^{14}$

Durante los primeros meses de 1923, los estudiantes de Cuba salieron a las calles pidiendo reformas universitarias: menos capitalismo y mayor libertad de asociación y pensamiento (Los cinco, 1927a: 97). En 1924, la Federación de Estudiantes Universitarios nació como vector de las reformas universitarias y sociales de la juventud. Aglutinó esfuerzos y coordinó acciones tanto en las aulas como en las calles. En 1928, el estudiantado publicó un manifiesto contra la erección de un monumento en conmemoración del Soldado español, que podía interpretarse como Cánovas, Weyler o Tacón.

Los cinco defendieron al unísono que Enrique José Varona se erigiese como líder intelectual de la juventud cubana. Se necesitaba un guía que definiese los objetivos nacionales y les incitase a la movilización. Solo en la pasividad de la ciudadanía residía la capacidad que el gobierno tenía para subyugarlo. Avance veía en la anunciada regeneración cubana la mecha que impulsaría la revolución en el resto del Caribe. Esta podía ser la vía para lograr la unión contra EE.UU. que «perdía progresivamente capacidad de influir en esa zona» (Los cinco, 1930f: 161).

En Avance también alentaron a la juventud de otros países. En Nicaragua, la problemática comenzaba a adquirir las mismas dimensiones que el caso cubano. El «Congreso Panamericano» fue el mayor intento por aunar esfuerzos en la creación de una identidad y unos objetivos comunes. En 1928 asistieron veinte naciones «de tronco ibérico y de ideales autóctonos, testificadoras y protestantes del imperialismo yanqui» (Los cinco, 1928a: 3). Los grandes propósitos quedaron para otra ocasión. Las cuestiones trascendentales fueron tratadas sucintamente.

Si se reduce la escala de análisis, Revista de Avance también se decantó por otro tipo de filiación, tanto cultural como política. José Martí soñó con una confederación antillana que, a la manera del Imperio Japonés, uniera a todas sus islas, especialmente a su población más joven (Los cinco, 1929o: 351). En este punto, el sentimiento de identidad no queda tan claro y se difuminan las barreras geográficas a las que aluden sus términos. En pureza, lo caribeño y lo antillano no eran ideas equivalentes, pero se usaron de forma indiscriminada para señalar aquellos territorios insulares de América Central. Los cinco lanzaron un mensaje de necesaria confraternidad: las islas del Caribe y las Antillas «habrían de sostenerse juntas o juntas habrían de perecer» (Los cinco, 1929o: 352). Sin embargo, como se apuntó en lo relativo al afrocubanismo, 
Haití fue postergado. Los mismos ensayistas de Avance criticaron la inmigración de haitianos y jamaiquinos ya que a su juicio provocaría una nueva africanización de la sociedad y de su cultura. El fantasma de la negritud y el «miedo al negro» seguía planeando por la isla como ocurría desde el siglo xx (Naranjo Orovio y González García, 1996).

\section{Antiimperialismo yankee. Semillas para una revolución}

Hasta el momento se ha analizado el europeísmo, el hispanoamericanismo y el antillanismo, elementos externos de cohesión nacional. Sin embargo, la identidad cubana de los años veinte no se puede comprender sin apelar a un factor que impulsó la unión del pueblo cubano por oposición y rechazo: el antiimperialismo estadounidense o antinorteamericanismo, "semilla que germina y crece en dirección ofensiva» (Ichaso, 1930a: 14-16). El hispanoamericanismo podía entenderse como un «contraimperialismo cultural», una hermandad invertebrada que surgió como reacción al neocolonialismo de EE.UU., América Latina y el Caribe. En esta expansión política y militar, Washington había llevado a cabo intervenciones militares, enmiendas constitucionales, manipulación a su favor de los tratados comerciales, dominio de sus gobiernos desde la sombra, apropiación de los bancos, expropiación de tierras cultivables, y control de las concesiones estatales a empresas privadas del ferrocarril o la construcción (Naranjo Orovio, 2003: 523).

La juventud revolucionaria que participó en la Protesta de los trece, el Grupo Minorista o la fundación del Partido Comunista se alzó en contra de la dominación extranjera. Enrique José Varona encabezó a un grupo de figuras tan relevantes como Emilio Roig, Rubén Martínez Villena y Julio Mella, pero también a quienes terminarían siendo directores de Revista de Avance, para fundar en julio de 1925 la Liga Antiimperialista. Luis Araquistain se mostró más comprometido en los acontecimientos y los lugares que ocuparon su estudio. En La agonía antillana (Los cinco, 1928c: 159), el escritor español calificó la política expansionista de EE.UU. no como «de especial interés», sino como «imperialismo norteamericano». Señaló que la presencia de Washington en el Caribe tenía su razón de ser en el control de las vías comerciales hacia Asia a través del Canal de Panamá, pero también supervisar el nivel de desarrollo capitalista que experimentan los países de la zona, evitando coaliciones o pactos que afectasen a sus intereses (Los cinco, 1927c: 125). Los cinco criticaron que algunos cubanos aún rindiesen gratitud hacia EE.UU. por su ayuda en la contienda contra España en 1898 y además se sintiesen admirados por el urbanismo de sus ciudades o el lujo de sus clubs de beisbol erigidos junto al Vedado (1929b: 35).

En la forja del sentimiento antiimperialista en Cuba encontramos dos vertientes con una misma raíz: sin la independencia económica respecto a EE.UU., los cubanos no podrían alcanzar su total emancipación política y tampoco estarían capacitados para desarrollar una tradición cultural propia (Marinello, 1929: 356). Avance intentó atender estas preocupaciones mediante manifestaciones, conferencias o ensayos-denuncia. ${ }^{15}$ No obstante, entre 1927 y 1930 el gobierno de Machado acordó una rebaja presupuestaria para la enseñanza pública, suprimió cátedras, recortó el salario del profesorado y redujo el número de asignaturas en la enseñanza secundaria y universitaria (Los cinco, 1930g: 193). En este contexto, se hacía muy complicado materializar el sueño de la «regeneración cultural» por la que se clamaba desde la revista.

Por su parte, algunas instituciones u organismos supranacionales con pretendido afán de hermandad demostraron ser completamente inoperativos. La «Sexta Conferencia Panamericana», por presión de los EE.UU. o por acuerdo mutuo, evitó tratar los temas más trascendentales para los que se había creado primeramente. Se esquivaron asuntos como la doctrina Monroe, la Enmienda Platt, la cuestión del Canal de Panamá o la política neocolonialista de Washington en Cuba (Los cinco, 1928a: 4).

A partir de 1928, revistas de México, Chile, Argentina y Cuba cambiaron su línea editorial. Algunas pasaron de la oposición frontal frente a EE.UU. al entendimiento o la convivencia; al menos con los medios más radicales. Ante la imposibilidad de cerrarse a la entrada de influencias estadounidenses, el equipo de Avance optó por establecer un diálogo con los jóvenes intelectuales estadounidenses de izquierdas mediante el mutuo intercambio de literatura, novela, teatro y pintura. Entre sus proyectos editoriales se encontraba la publicación de un monográfico para dar a conocer la literatura norteamericana en Cuba, aunque nunca se publicó (Los cinco, 1928d: 236). Asimismo, intentaron dar cabida a los jóvenes talentos norteamericanos, Henry Mencken, Clarence Darrow, Stark Young, Ezra Pound, Sinclair Lewis o John dos Passos (Los cinco, 1928e: 267-268). Entre estos, merecen mención especial por su vinculación con la revista, Teodoro Dreiser y Sherwood Anderson (Anderson, 1927: 115). Consideraban que esta era la vía para fomentar las relaciones entre grupos de intelectuales. En otro aspecto, Avance pretendía enviar publicaciones cubanas y recibir otras estadounidenses con el objetivo de fomentar el diálogo cultural entre ambas orillas (Los cinco, 1930j: 288). Por su parte, Pedro Sanjuán, director de la Filarmónica de La Habana y colaborador de la revista, aceptó dirigir una serie de conciertos en Los Ángeles y New York (Los cinco, 1927f: 82).

\section{CONCLUSIÓN}

Revista de Avance constituyó una publicación de referencia entre los sectores culturales más vanguardistas de Hispanoamérica. El enfoque transgresor, innovador y rupturista que sus editores mantuvieron en el arte puede explicarse por los antecedentes políticos de sus directores -socialistas, comunistas y regeneracionistas-, pero también se observa en actuaciones posteriores a su fundación. La revista, que nació para dar cabida a los nuevos artistas del continente, terminó ofreciendo una visión crítica de la situación que atravesaba Cuba a finales de los años 20'. 
En ese afán de contribuir a la regeneración nacional se vieron obligados a preguntarse primeramente de dónde provenían y cuál era la problemática contemporánea para saber hacia dónde dirigirse. Es decir, desde diferentes enfoques y disciplinas -arte, política, historia-, Revista de Avance analizó los ingredientes que constituía y que no debía constituir el «ser cubano» para después realizar propuestas regeneracionistas. Como hiciera Fernando Ortiz años después, no interpretaron la variedad étnica como un factor de retraso frente a los Estados Unidos y Europa, sino como una riqueza que podía ser aprovechada en su favor. Solamente había que ofrecer una relectura de sus respectivos legados culturales en clave nacionalista, representándolas como las raíces que sostienen y alimentan un mismo tronco común. En definitiva, el objetivo era revertir el concepto negativo que se tenía de la pluralidad étnica para cohesionar a la ciudadanía cubana y hacer de la hasta entonces patria criolla una nación de cubanos. De hecho, como se ha visto, Revista de Avance atesora el mérito de haber sido la primera revista cubana dirigida por élites blancas que intentó poner en valor el legado afrocubano. En este aspecto está claro, como decían Gellner y Anderson, que es el nacionalismo quien engendra las naciones, no a la inversa.

El papel de los intelectuales como forjadores de patrias fue condicionante, pero nunca suficiente. ${ }^{16}$ La utopía de la unificación social en los años 20' solo se pudo empezar a poner en marcha mediante un doble movimiento: por un lado, cuando se añadió a los grandes referentes de la historia pasada -los hitos y mitos referenciales y aleccionadores-, la cultura de lo popular (Ibarra, 1981: 9-33). Por otro, cuando el hombre blanco se sintió atraído por la negritud, aunque en un principio fuera con la lente de lo exótico (Opatrný, 1986). Los editores y ensayistas de Avance, con sus condicionantes personales, profesionales e ideológicos, solo hicieron de intermediarios letrados entre «el pueblo y el mismo pueblo». Tomaron sus herencias culturales, sus tradiciones folclóricas y populares para devolvérselas transformadas en elementos identificativos y constituyentes de la cubanidad a través de publicaciones e instituciones. ${ }^{17}$ En otras palabras, los intelectuales inspiraron y sustentaron su propuesta de relato identitario para reforzar los vínculos de la sociedad en las aportaciones que esta misma le hacía. Ahora bien, valorar hasta qué punto sus ideas y conceptos fueron asimilados y se vieron correspondidos es un aspecto que escapa a la presente investigación. Sirva decir que Avance coordinó varias exposiciones de jóvenes artistas americanos y propuso en ocasiones llevar a cabo misiones educativas a las zonas rurales donde la gente no tenía acceso a los eventos que se organizaban en Santiago, Matanzas o La Habana.

Revista de Avance dejó de publicarse en septiembre de 1930 ante la censura de prensa decretada por Gerardo Machado. Así llegó a su fin una empresa cultural que había sido fiel a una ideología y a una ética de trabajo, ${ }^{18}$ pero siendo consciente de que sus metas aún no habían sido conseguidas. Los conflictos entre etnias no se detuvieron, mientras que la cuestión de la identidad nacional en Cuba continuaría siendo objeto de debate. Durante los convulsos años treinta, las élites culturales y políticas instrumentalizaron, cada una a su manera, el relato histórico, la tradición o el concepto de progreso para justificarse frente a la nación que gobernaban o sobre la que se pretendía influir.

A lo largo del presente artículo se ha intentado poner en valor la metáfora que Juan Marinello utilizó para resumir la concepción martiana de la nación cubana: «Ala y raíz» (Los cinco, 1929j: 314). Alas del ave antillano, que henchida de juventud quería alzar el vuelo para desprenderse del imperialismo estadounidense. Ave siempre en deuda con la raigambre de su herencia indígena, europea y africana. Raíz que se ensanchaba en un espectro de diversidad cultural y racial en la que se diluía el criollismo blanco junto a la hipotecada azúcar de los ingenios y el sudor de los braceros sobreexplotados. En efecto, la Cuba de los años veinte era una nación en construcción que se buscaba a sí misma en un bosquejo de impotencias y aspiraciones tensadas al punto del desgarro; como las cuerdas de una guitarra que intentan aguantar el envite de dos voluntades forcejeando en direcciones opuestas: el aleteo de la liberación nacional y las raíces que se aferraban a la herencia hispanoamericana.

\section{AGRADECIMIENTOS}

Este artículo toma como base el material utilizado para la elaboración del Trabajo Final de Máster titulado Ala y raíz: la forja de la identidad nacional en Cuba. El ejemplo de la Revista de Avance (1927-1930), defendido en la Universidad de Castilla-La Mancha en septiembre de 2012, estudio realizado bajo la dirección de los profesores Juan Sisinio Pérez Garzón y Consuelo Naranjo Orovio. La sección referida a negritud y afrocubanía fue presentada en el Seminario Internacional: Marcadores del tiempo en las Antillas, celebrado en La Habana en abril de 2014 (organizado por la Casa de las Américas, la Casa de Velázquez y el Consejo Superior de Investigaciones Científicas) bajo el título «Élites blancas en defensa de la cultura afrocubana: Revista de Avance, (1927-1930)». Parte del texto ha sido desarrollado gracias a la financiación del Proyecto Nacional I+D HAR2012-37455-C03-01, Marcadores del tiempo: Continuidades y discontinuidades en las sociedades hispanoantillanas, siglos XIX Y XX, cuya investigadora principal es la profesora Consuelo Naranjo Orovio.

\section{NOTAS}

1. Para consultar digitalmente el texto original de la Enmienda Platt, se puede acudir a la página web de la Universidad Nacional de México, www.jurídicas.unam.mx, concretamente al enlace http://www.bibliojuridica.org/libros/6/2525/15.pdff (consultado 24-06-2014).

2. A nivel general, se puede consultar Hugh Thomas (2012) Cuba. La lucha por la libertad. Debolsillo, Barcelona: 398.

3. Los fundadores del Grupo Minorista fueron Francisco Ichaso (Periodista), Félix Lizaso (Crítico), Jorge Mañach (Periodista), Juan Marinello (Ensayista), José Zacarías Tallet (Escritor), Alejo Carpentier (Escritor), Eduardo Abela (Pintor), Agustín Acosta (Poeta), Juan Antiga (Médico), Luis Alejandro Baralt Zacharie (Crítico de Arte), Diego Bonilla (Violinista), Otto Blunme 
(Médico), Marti Casanovas (Periodista), Primitivo Cordero Leyva (Abogado), José Antonio Fernández de Castro (Periodista), José Ramón García Espinosa (Abogado), Antonio Gattorno (Pintor, Luis Gómez Wangüemert (Periodista), Max Henríquez Ureña (Escritor dominicano), José Hurtado de Mendoza (Pintor). Federico de Ibarzábal (Periodista), Alberto Lamar Schweyer (Periodista), Luis López Méndez (Pintor), Armando Maribona (Periodista y pintor), Juan Luis Martín Corona (Periodista) María Villas Buceta (Poeta), Guillermo Martínez Márquez (Periodista), Rubén Martínez Villena (Periodista), Calixto Masó (Ensayista), Conrado Massaguer (Caricaturista), Felipe Pichardo Moya (Poeta), Alfredo T. Quílez (Periodista), Emilio Roig de Leuchsenring (Periodista e historiador), Arturo Roselló (Periodista), Enrique Serpa (Periodista), Juan José Sicre (Escultor), Jaime Valls (Dibujante), Orosmán Viamontes (Periodista). Los cinco primeros integraron la dirección de $R e$ vista de Avance en algún momento entre el 15 de marzo de 1927 y el 30 de septiembre de 1930.

4. Las identidades no solo se construyen en base a elementos internos o vínculos internacionales positivos, sino también por oposición a lo extranjero, a lo bárbaro, al opresor, al otro. Tzvetan Todorov (2012) Nosotros y los otros. Siglo XXI, Madrid; (2011) Vivir solos juntos. Galaxia Gutenberg, Madrid, (2010) La conquista de América: El problema del otro. Siglo XXI, Madrid y (2008) El miedo a los bárbaros. Galaxia Gutenberg, Madrid; François Hartog (2000) El Espejo de Heródoto. Ensayo sobre la representación del otro. $5^{\mathrm{a}}$ edición. FCE, Buenos Aires; Josep Fontana (2000) Europa frente al espejo. Crítica, Barcelona.

5. «Como contrapunto a estas ideas, ya entrada la década de los veinte, Fernando Ortiz comienza a elaborar otra idea sobre la cubanidad $[\ldots]$ uno de los principales intelectuales que elaboraron un nuevo imaginario nacional, en el que las diferencias de color y de cultura fueran elementos de riqueza y no de exclusión, pobreza o degeneración. Fue precisamente en el estudio de las culturas y no de las razas lo que desembocó en la definición de la cubanidad como una categoría cultural en la que se fusionaban todos los aportes étnicos de la isla».

6. «Los cinco» era el nombre utilizado por los directores de Revista de Avance para firmar los editoriales y artículos conjuntos de la revista.

7. «Hombre es más que blanco, más que mulato, más que negro. Cubano es más que blanco, más que mulato, más que negro. En los campos de batalla, muriendo por Cuba, han subido juntas, por los aires, las almas de los blancos y de los negros». Los cinco (1930) «Pigmento y civilidad». Revista de Avance, 45: 98.

8. Al respecto, resultan impactantes las siguientes palabras publicadas en este artículo: «[...] levantó el brazo de Kid Chocolate y un tufo de axila victoriosa se esparció por el campo. Momento histórico: una jornada más en la liberación del «negrito», Los cinco (1929e) «Kid chocolate o el negrito». Revista de Avance, 35: 182 .

9. «Cuerdas de la guitarra / caminos de las arañas de los dedos! / Caminando, caminando, las arañas trabajan los sonidos [...] Los payadores siguen / en el telar de las cuerdas, / tejiendo canciones gauchas». Ildefonso Pereda Valdés (1927) «De la guitarra de los negros». Revista de Avance, 12: 316.

10. Para ver algunas de sus pinturas, hay que acudir a Domingo Ravenet, Revista de Avance, 1927, 8: 204d y 1927, 8: 204d. José Clemente, 1927, 17: 117; Conrado W. Massaguer, 1930, 49: 245. Carlos Mérida, 1929, 30: 22; López Méndez, 1930, 49: 249; Roberto Aciaga, 1930, 49: 257 y 1930, 50: 263 y Gabriel García Maroto, 1930, 50: 281.

11. El problema del ennegrecimiento derivó, ya en el siglo XIX, en políticas racistas de blanqueamiento con el objetivo de buscar la pureza y el progreso de la raza, como vemos en José Gomariz, «Gertrudis Gómez de Avellaneda y la intelectualidad reformista cubana. raza, blanqueamiento e identidad cultural», Sab, Vol. 37, 1 (January - June 2009): 100 (consultado en http:// redalyc.uaemex.mx/pdf/392/39213080004.pdf. 20/06/2014) Para el siglo xx, Armando García González y Raquel Álvarez Peláez (2007) Las trampas del poder. Sanidad, eugenesia y migración: Cuba y Estados Unidos (1900-1940). Madrid, 2007 y Armando García González y Raquel Álvarez Peláez (1998) En busca de la raza perfecta. Eugenesia e higiene en Cuba (1898-1958). Madrid, CSIC.

12. «Autorizando a la Compañía Azucarera Atlantic Frutera y Azucarera de Cuba, para introducir en el país por el puerto de Sagua de Tánamo tres mil braceros antillanos para efectuar trabajos agrícolas». (Extraído de Diario de la Marina, Oct. 25. 1929), Los cinco (1929n) «Lo que contiene de trágico la Gaceta». Revista de Avance, 40: 320.

13. Hay varios estudios sobre la cuestión. Entre otros pueden consultarse: James T. Campbell, Matthew Pratt Guterl y Robert G. Lee (2007) Race, nation \& empire in American History. Chapell Hill, University of North Carolina Press; Alejandro De la Fuente (1999) «Myths of racial democracy: Cuba, 1900-1912». Latin American Research Review: Vol. 34, 3: 39-73; Consuelo Naranjo Orovio y Armando García González (1996) Medicina y racismo en Cuba: la ciencia ante la inmigración canaria en el siglo XX. La Laguna, Tenerife; Centro de la Cultura Popular Canaria; Tomás Fernández Robaina (1990) El negro en Cuba: 1902-1958: Apuntes para la historia de la lucha contra la discriminación racial, La Habana, Editorial de Ciencias Sociales.

14. Aunque en algunos casos, especialmente a pocos números del final de su publicación, Los cinco se mostraron algo escépticos sobre la viabilidad de este proyecto si no existía una articulación de fuerzas juveniles a nivel internacional o si esta se efectuaba sin intensidad ni continuidad; como se puede ver en Los cinco (1930) «Señales del norte». Revista de Avance, 42: 3.

15. Alguno de sus colaboradores, como Emilio Roig de Leuchsenring, optaron por la acción directa en la calle, espoleando los ánimos del proletariado mediante panfletos o encabezando manifestaciones, como podemos ver en Los cinco (1927c) «Los problemas sociales en Cuba, por Emilio Roig de Leuchsenring». Revista de Avance, 6: 146.

16. Como señalaron Martí Casanovas y Jorge Mañach para Avance, y años después Pierre Bourdieu y Dellanoi.

17. Tres de ellas fueron la Institución Hispano-cubana de Cultura, la Universidad de La Habana y la Universidad Popular José Martí.

18. Uno de sus más importantes criterios de publicación fue dar paso a los nuevos artistas cubanos primero, americanos después. A la altura de 1930, Los cinco se sienten orgullosos por la labor realizada, pues «[...] La lista de escritores cubanos, desconocidos o casi ignorados que hemos traído a estas páginas, es nuestra mejor palabra, porque ya se sabe que una revista, más que por lo conocido que publica, así sea lo mejor, vale por lo nuevo que revela [...] Lino Novás Calvo, Eugenio Florit, Tomás Castañeda Ledón, Emilio Ballagas, Pedro Marco, Raúl Maestri, Raúl Roa». Los cinco (1930d) «Vuelta al tema». Revista de Avance, 46: 131; R. Maestre Arredondo (1928) «Balance literario 1928». Revista de Avance, 29: 343, y Los cinco (1930h) «Edward Bello, Joaquín». Revista de Avance, 47: 188. «[...] A veces se cruzan sin que logremos aprehenderlos, pero no sin que su vibración se haga sentir, de uno u otro modo, en esta estación. Si la respuesta se hace tardar, la culpa ha de caer en las excesivas solicitudes que cruzan nuestros alambres. La convergencia abrumadora de corrientes es a veces una sola resistencia a vencer $[\ldots] »$.

\section{REFERENCIAS}

Álvarez Junto, José; Beramendi, Justo y Requejo, Ferran (2005) $E l$ nombre de la cosa. Debate sobre el término 'nación' y otros concepto relacionados. Centro de Estudios Políticos y Constitucionales, Madrid.

Anderson, Sherwood (1927) «Teodoro Dreiser». Revista de Avance, 5: 115 .

Andreo García, Juan (2013) «No hay tamarindo dulce ni mulata señorita'. La construcción de identidades de raza y género en la cuba de finales del periodo colonial». En Afroamérica, espacios e iden- 
tidades, Icaria/Antrazyt América Latina, Barcelona, editado por Javier Laviña; Ricardo Piqueras y Cristina Mondejar: 181-203.

Benjamin, Jules R. (1975) «The Machadato and Cuban Nationalism, 1928-1932». The Hispanic American Historical Review, vol. 55, 1: 66-91

Bouffartigue, Silvie (2006) «Apuntes sobre la invención de una cultura de lo nacional en Cuba». En Nación y cultura nacional en el Caribe hispano. Karolinum, Praga, Josef Opatrný: 17-23.

Bourdieu, Pierre (1999) Intelectuales, politica y poder. Eudeba, Buenos Aires.

Breully, John (1990) Nacionalismo y Estado. Ed. Pomares-corredor, Barcelona.

Campbell, James T.; Pratt Guterl, Matthew y Lee, Robert G. (2007) Race, nation and empire in American History. Chapell Hill, University of North Carolina Press.

Cardoza y Aragón, Luis (1930) «El romance de Federico García Lorca». Revista de Avance, 44: 74.

Carpentier, Alejo (1930) «Liturgia». Revista de Avance, 50: 260.

Castañeda León, Tomás (1929) «De la Sique Africana». Revista de Avance, 32: 110.

D’Ors, Eugenio (1927) «Recuerdos sobre México y Cuba». Revista de Avance, 19: 40.

De la Fuente, Alejandro (1999) «Myths of racial democracy: Cuba, 1900-1912». Latin American Research Review, vol. 34, 3: 39-73.

De la Fuente, Alejandro (2000) Una nación para todos. Colibrí, Madrid.

Fernández Robaina, Tomás (1994) El negro en Cuba: 1902-1958: Apuntes para la historia de la lucha contra la discriminación racial. Editorial de Ciencias Sociales, La Habana.

Fontana, Josep (2000) Europa frente al espejo. Crítica, Barcelona.

García González, Armando y Álvarez Peláez, Raquel (2007) Las trampas del poder. Sanidad, eugenesia y migración: Cuba y Estados Unidos (1900-1940). CSIC, Madrid.

García González, Armando (1998) En busca de la raza perfecta. Eugenesia e higiene en Cuba (1898-1958). CSIC, Madrid.

García Maroto, Gabriel (1930) «Picasso y el arte de siempre». Revista de Avance, 46: 152.

Hartog, François (2003) El Espejo de Heródoto. Ensayo sobre la representación del otro. $5^{\mathrm{a}}$ ed., FCE, Buenos Aires.

Ibarra, Jorge (1981) Nación y cultura nacional. Editorial Letras $\mathrm{Cu}-$ banas, La Habana.

Ichaso, Francisco (1927) «La crisis del respeto». Revista de Avance, 11: 274 .

Ichaso, Francisco (1928) «La Rebambaramba». Revista de Avance, 26: 244.

Ichaso, Francisco (1930a) «Cura de Verdad». Revista de Avance, 42: 14-16.

Ichaso, Francisco (1930b) «Liturgia negra». Revista de Avance, 46: 158 .

Jarnes, Benjamin (1929) «Raza, grillete». Revista de Avance, 30: 8.

Jeanneret, Albert (1927) «El negro y el Jazz». Revista de Avance, 12: 314 .

Lizaso, Félix (1929) «Programa de criolledad». Revista de Avance, 40: 358 .

Lizaso, Félix (1930) «Waldo Frank y las dos Américas». Revista de Avance, 42: 11.

Los cinco (1927a) «Veinte y cinco años de república». Revista de Avance, 5: 97.

Los cinco (1927b) «La tragedia nicaragüense». Revista de Avance, 6: 125 .

Los cinco (1927c) «Los problemas sociales en Cuba, por Emilio Roig de Leuchsenring». Revista de Avance, 6: 146.

Los cinco (1927d) «Congaree Sketches, por E.C.L. Adamas., Carolina Press». Revista de Avance, 12: 318.

Los cinco (1927e) «De Jaime Valls». Revista de Avance, 15: $72 \mathrm{~A}-72 \mathrm{C}$.

Los cinco (1927f) «El maestro San Juan en los Estados Unidos». Revista de Avance, 15: 82.

Los cinco (1927g) «Tierra y población en las Antillas». Revista de Avance, 16: 87.

Los cinco (1928a) «El sexto Congreso Panamericano». Revista de Avance, 18: 3-4.
Los cinco (1928b) «Cultura y provincialismo». Revista de Avance, 22: 108 y 135

Los cinco (1928c) «La agonía antillana, por Luis Araquistain. Espasa-Calpe, Madrid». Revista de Avance, 23: 159.

Los cinco (1928d) «Proyectos. Perspectivas». Revista de Avance, 26: 236.

Los cinco (1928e) «Boomerang». Revista de Avance, 27: 267-268.

Los cinco (1928f) «Seis ensayos en busca de nuestra expresión, por Pedro Henríquez Ureña. Babel. Buenos Aires». Revista de Avance, 27: 291.

Los cinco (1929a) «La cuestión del negro». Revista de Avance, 30: 5.

Los cinco (1929b) «El momento cubano». Revista de Avance, 31: 35.

Los cinco (1929c) «El señor Morand y las Antillas». Revista de Avance, 32: 64 .

Los cinco (1929d) «La revolución mexicana, por Luis Araquistain». Revista de Avance, 32: 86.

Los cinco (1929e) «Kid chocolate o el negrito». Revista de Avance, 35: 182.

Los cinco (1929f) «Babaluaye». Revista de Avance, 36: 217.

Los cinco $(1929 \mathrm{~g})$ «La crisis del patriotismo por Alberto Lamar Scheweyer». Revista de Avance, 37: 243.

Los cinco (1929h) «Cuba. Caso Antillano». Revista de Avance, 39: 287.

Los cinco (1929i) «El puño y la inteligencia». Revista de Avance, 39: 289.

Los cinco (1929j) «Tres notas martinianas». Revista de Avance, 39: 313.

Los cinco (1929k) «El milagro del Anaquille». Revista de Avance, 39: 314.

Los cinco (19291) «Las conferencias de Barcia Trelles». Revista de Avance, 39: 315.

Los cinco (1929m) «Viaje a América». Revista de Avance, 40: 319.

Los cinco (1929n) «Lo que contiene de trágico la Gaceta». Revista de Avance, 40: 320.

Los cinco (1929o) «Mensaje a Puerto Rico». Revista de Avance, 41: 351.

Los cinco (1930a) «Señales del norte». Revista de Avance, 42: 3.

Los cinco (1930b) «Pigmento y civilidad». Revista de Avance, 45: 98.

Los cinco (1930c) «Amor y geografía». Revista de Avance, 46: $130-131$.

Los cinco (1930d) «Vuelta al tema». Revista de Avance, 46: 131.

Los cinco (1930e) «Liturgia negra». Revista de Avance, 46: 158.

Los cinco (1930f) «Palabras de Varona». Revista de Avance, 47: 161.

Los cinco (1930g) «Economía, política, cultura». Revista de Avance, 47: 193.

Los cinco (1930h) «Edward Bello, Joaquín». Revista de Avance, 47: 188.

Los cinco (1930i) «Motivos y letras de España, por Rufino BlancoFombona. C. Iberoamericana de Publicaciones, Madrid». Revista de Avance, 49: 250.

Los cinco (1930j) «Nota importante». Revista de Avance, 50: 288.

Maestre Arredondo, R. (1928) «Balance literario 1928». Revista de Avance, 29: 343.

Mañach, Jorge (1929) «Vértice del gusto nuevo». Revista de Avance, 34: 130 .

Mañach, Jorge (1930) «El artista y sus imágenes. Jaime Valls». Revista de Avance, 45: 112

Marco, Pedro (1929) «Moda y Modo Negros». Revista de Avance, 35: 181.

Marinello, Juan (1928) «Arte y política». Revista de Avance, 18: 7.

Marinello, Juan (1930) «La inquietud cubana». Revista de Avance, 41: 356.

Marinello, Juan (1930) «Sobre la inquietud cubana (2)». Revista de Avance, 42: 57.

Morand, Paul (1929) «El zar negro». Revista de Avance, 30: 20.

Naranjo Orovio, Consuelo (1998) «Cuba, 1898: Reflexiones en torno a los imaginarios nacionales y a la continuidad». Cuadernos para Historia Contemporánea, 20: 221-239.

Naranjo Orovio, Consuelo (2001) «La historia se forja en el campo: nación y cultura en Cuba en el siglo XX». Historia Social, 40: $153-174$.

Naranjo Orovio, Consuelo (2003) «Creando imágenes, fabricando historia: Cuba en los inicios del siglo Xx». Historia Mexicana, vol. 53, 2 (210): 511-540.

Naranjo Orovio, Consuelo y García González, Armando (1996) Medicina y racismo en Cuba: la ciencia ante la inmigración cana- 
ria en el siglo xx. Centro de la Cultura Popular Canaria, La Laguna, Tenerife.

Núñez Vega, Jorge Alejandro (2011) La Danza de los Millones. Modernización y cambio cultural en La Habana (1915-1920). Universitat Pompeu Fabra, Barcelona [Tesis Doctoral UPF, Barcelona].

Opatrný, Josef (1986) Antecedentes históricos de la formación de la nación cubana. Universidad Carolina, Praga.

Pereda Valdés, Ildefonso (1927) «De la guitarra de los negros». Revista de Avance, 12: 316.

Pérez Garzón, Juan Sisinio (2002) «Usos y abusos de la historia». Gerónimo de Uztariz, 17/18: 11-24.

Perón Hernández, Greta (2012) «Pedro Sanjuán y el afrocubanismo musical en el contexto de la vanguardia cubana de la década de 1920». Cuadernos de Música Iberoamericana, 23: 87-106.

Pichardo, Hortensia (1985) José Martí. Lecturas para niños. Editorial Oriente, Santiago de Cuba.

Quiroga, Domingo (1929) «Claxon». Revista de Avance, 35: 167.

Roa García, Raúl (1927) «Martí, poeta nuevo». Revista de Avance, 10: 254 .

Rodríguez, L. F. (1930) «La danza lucumí». Revista de Avance, 42: 47.
Rojas, Rafael (2000) José Martí: la invención de Cuba. Colibrí, Madrid.

Said, Edward (2006) Humanismo y crítica democrática. La responsabilidad pública de escritores e intelectuales. Debate, Barcelona.

Santamaría, Antonio (2001) Sin azúcar no hay país. La industria azucarera y la economía cubana (1919-1939). CSIC, Sevilla.

Tamayo, Francisco (1927) «Universalismo español». Revista de Avance, 4: 95.

Thomas, Hugh (2012) Cuba. La lucha por la libertad. Debolsillo, Barcelona.

Todorov, Tzvetan (2008) El miedo a los bárbaros. Galaxia Gutenberg, Madrid,

Todorov, Tzvetan (2010) La conquista de América: El problema del otro. Siglo XXI, Madrid.

Todorov, Tzvetan (2011) Vivir solos juntos. Galaxia Gutenberg, Madrid.

Todorov, Tzvetan (2012) Nosotros y los otros. Siglo XXI, Madrid.

Zamora, Adolfo (1929) «Eduardo Abela, pintor cubano». Revista de Avance, 30: 18. 